\title{
К БИОГРАФИИ Ю. Г. ОКСМАНА \\ (По материалам Центрального государственного исторического архива Санкт-Петербурга)
}

\author{
М. Г. Сальман \\ (С.-Петербург)
}

Задача настоящей работы - сообщить несколько подробностей о юношеских годах Юлиана Григорьевича Оксмана и прокомментировать его автобиографические наброски и мемуарные заметки, отчасти уточнив их и дополнив. Основой для статьи послужило студенческое дело Оксмана, хранящееся в Центральном государственном историческом архиве С.-Петербурга ${ }^{1}$. Все даты приводятся по старому стилю, даты по новому стилю специально оговариваются. Документы публикуются по правилам современной орфографии и пунктуации, сохраняется, однако, написание прописных букв. Общеизвестные имена (С. А. Венгеров, А. А. Шахматов, Л. В. Щерба и т. п.) не комментируются.

Отец Ю. Г. Оксмана, Герш Менделев (в русифицированном варианте - Григорий Эммануилович) Оксман, по свидетельству его внучки, «родился в 1861 г. в Каменце-Подольском» (Оксман 2008: $24)^{2}$. О. Э. Оксман также сообщает, что после окончания гимназии ее дед $«<. .>$ приехал в Петербург $<\ldots .>$ и учился на естественномедицинском факультете» (Там же: 25). Хранящийся в студенческом деле Ю. Г. Оксмана кондуитный список фармацевтической деятельности его отца опровергает это утверждение. До того как стать аптекарем ${ }^{3}$ в Вознесенске, заштатном городе Елисаветградского

1 ЦГИА СПб. Ф. 14. Оп. 3. Д. 63266. В дальнейшем указываем только номер дела и лист. 2 Ольга Эммануиловна Оксман - дочь младшего брата Ю. Г. Оксмана, Э. Г. Оксмана, о нем см. на сайте Сахаровского центра: [http://www.sakharov-center.ru/asfcd/auth/?t= author\&i=1549].

3 Химиком-бактериологом назвал его Оксман в автобиографии 1949 года, см.: Зайцев 1990: 526. Дата написания автобиографии приведена на с. 530. То же: Пугачев, Динес 1995: 8. 
уезда, Херсонской губернии России. Неизвестно, окончил ли он полный курс или только шесть классов классической гимназии, что требовалось для поступления в аптекарские ученики (см.: Брокгауз, Ефрон 1890: 933). Вполне возможно, что он держал экзамены экстерном. В любом случае, чтобы получить право выдержать экзамен на звание аптекарского помощника, он должен был пройти обязательную практику в аптеке в течение двух (если у него был аттестат о среднем образовании) или трех лет (если он имел свидетельство об окончании шести классов) (см.: Там же). Выдержав при Харьковском университете испытание, Герш Оксман был «удостоен степени Аптекарского помощника 1883 ноября $28 »^{5}$, после чего поступил «в Одесскую вольную аптеку провизора Беера» ${ }^{6}$, где пробыл полгода. Оттуда он перебрался в Балту, где немногим более года прослужил в вольной аптеке провизора Ландау. В августе 1885 он уже в Кременчугской вольной аптеке, откуда переезжает в Москву, где служит в вольной «Сухаревской аптеке с 1886 сентября 7 по 1887 апреля 15». Две летние недели 1887 Герш Оксман пробыл в Каменецкой вольной аптеке провизора Подгаецкого, о двух следующих годах его жизни кондуитный список умалчивает. Можно предположить, что подобная «волатильность» - «летун», сказали бы при советском режиме, - объяснялась не дурным характером аптекарского

4 Заштатный город - не являющийся административным центром уезда. Сейчас Николаевская область, Украина.

5 Д. 63266. Л. 36.

6 Там же. Аптеку можно было открыть лишь «с разрешения губернатора на основании представления о том местного врачебного правления» (Брокгауз, Ефрон 1890: 932). Еще до открытия аптека подвергалась подробному осмотру врачебного отделения губернского правления, закон определял, сколько комнат и сколько каких принадлежностей должна иметь аптека. Местное медико-полицейское управление надзирало «за правильным дежурством, правильным отпуском лекарств по рецептам врачей <...» (Там же. 933). Рецепты вносились в хранившуюся в аптеке рецептурную книгу, сигнатуры хранились в течение 3 лет, цена лекарств должна была «сообразоваться с последней изданной таксой» (Там же), которая утверждалась медицинским советом министерства внутренних дел. Персонал аптеки мог состоять из учеников, аптекарских помощников, провизоров и магистров.

7 Д. 63266. Л. 36. 
помощника, а старой ремесленной традицией, требовавшей набраться опыта и поработать в разных городах и у разных хозяев. Чтобы получить право держать экзамен на провизора, аптекарский помощник должен был прослужить в аптеке три года и только затем допускался к слушанию университетского фармацевтического курса (см.: Брокгауз, Ефрон 1890: 933). В декабре 1889 Герш Оксман выдержал «экзамен на степень провизора в Императорском Московском Университете по медицинскому факультету <,> на что имеет свидетельство от 23 декабря 1889 за № $3529 »^{8}$. С февраля 1891 по июнь 1892 Оксман управлял «Александровским аптечным Отделением Раменской аптеки Чигиринского уезда»" в августе 1893 он оказался в Вознесенске, где несколько месяцев управлял «нормальной аптекой Кранца» ${ }^{10} .13$ января 1894 Герш Оксман взял в аренду вознесенскую городскую аптеку11, то есть, как через много лет его сын напишет в автобиографии, стал служащим «городского общественного самоуправления» (Зайцев 1990: 526. То же: Пугачев, Динес 1995: 8). Предположение, высказанное исследователем, что отец Ю. Г. Оксмана был владельцем аптеки да еще и довольно состоятельным (см.: Каганович 2006: 50-51), вряд ли имеет под собой основание: в кондуитном списке, выданном 26 мая 1907 врачебным отделением Херсонского губернского правления, оговаривалось, что Оксман «аптекой в Херсонской губернии не владел и не владеет» ${ }^{12}$. Спустя полтора года после того, как Герш Менделевич Оксман обосновался в Вознесенске, пятого января 1895 у него родился первенец - Юлиан.

Датой его рождения принято считать 30 декабря 1894. Она фигурирует в списке участников Пушкинского семинария при Петроградском университете (см.: Пушкинист 19166: 291), ее же

8 Там же.

9 Там же.

10 Там же.

11 См.: Там же.

12 Там же. Л. 36 об. Ср. с утверждением вдовы ученого Антонины Петровны Оксман (1895-1984), что отец Ю. Г. Оксмана «был владельцем аптеки в Тирасполе <..>» (Чудакова, Тоддес 1988: 97) и сообщением внучки, что в Тирасполе жил двоюродный брат Герша Оксмана, по профессии зубной врач, см.: Оксман 2008: 24. 
приводит Литературная энциклопедия (см.: ЛЭ 1934, VIII: 269) ${ }^{13}$, Краткая литературная энциклопедия (см.: КЛЭ 1968, 5: 411) ${ }^{14}$ и современные исследователи Д. И. Зубарев (см.: Писатели-диссиденты 2004: 425) и М. А. Фролов ${ }^{15}$, наконец, ее называет сам ученый в автобиографических записках 1960-х гг. (см.: Чудакова, Тоддес 1984: 81; то же: Зайцев 1990: 526). Между тем в curriculum vitae, приложенном к письму И. А. Шляпкину ${ }^{16}$ от 7 мая 1917, Оксман писал, что он родился 5 января 1895 (см.: Рак, Эльзон 2003: 145). Однако комментаторы письма предположили, что дату своего рождения Оксман указал по новому стилю и, отсчитав назад 12 дней, получили 24 декабря 1894, уточнив при этом, что ученый отмечал

13 Указан только год рождения.

14 Автор заметки - А. В. Белинков, см.: Абросимова 1998: 139. В некрологе, посвященном Оксману, Г. П. Струве писал: «Самое авторство первоначальной заметки и фиктивная подпись под ней представляют немалый интерес, но об этом говорить сейчас, пожалуй, еще преждевременно» («Тамиздат» 1990: 91). Струве пишет «первоначальной», так как заметка, «уже подписанная к печати, была искажена и сокращена вдвое <...» (Водонос, Филиппов 1994: 119. Письмо Оксмана от 13 декабря 1968). Об источнике подписи под заметкой в КЛЭ «Б. И. Колосова» см. в передаче радио «Свобода»: «Прием белой собачки. Аркадий Белинков и советская цензура» [http:// www.svoboda.org/content/article/27438670.html]. Опубликовано 21 декабря 2015.

15 Ср.: «<.. > родился 11 января 1895 года» (Фролов 2014: 111). Дата указана исследователем по новому стилю.

16 Илья Александрович Шляпкин (1858-1918), доктор русского языка и словесности, профессор (см.: Отчет 1914: 11, 3-я паг.). Чл.-корр. АН (1907). В первом и втором семестрах Оксман слушал его лекции по истории русской словесности (см.: Д. 63266. Л. 20 об. Л. 21), в третьем и четвертом семестрах занимался в просеминарии Шляпкина по истории древнерусской литературы и получил зачет 6 апреля 1915 (см.: Там же. Л. 18 об. - 19). Выпускное сочинение Оксмана, посвященное журналу «Московский вестник», было зачтено профессором 14 февраля 1917 (см.: Там же. Л. 15 об. - 16). В письме к Шляпкину Оксман сообщал, что его исследование “"Московский вестник (1827-1830)" Опыт истории журнала, его состав и значение в рус $<$ ской $>$ журналистике пушкинской поры с двумя приложениями: 1) Указатель к журна<лу> и 2) Исследование об авторах анонимных статей <...» было принято Б. Л. Модзалевским «для одного из академич<еских> изданий» (Рак, Эльзон 2003: 145, 146). Рукопись не сохранилась, о работе над этим сочинением см. ниже. «Осмысленную любовь к книге мне привили Н. М. Лисовский и И. А. Шляпкин (не столько их лекции, сколько домашнее общение с ними в пору 1914-1916 гг.)», - писал Оксман П. Н. Беркову 23 октября 1965 (Рак, Эльзон 2006: 233). На похоронах Оксмана С. М. Бонди заметил: «Я помню, как мы с Юлианом в 1918-м несли тяжелейший гроб профессора Шляпкина» (Эйдельман 1999: 150 - 151). О Н. М. Лисовском см. ниже. 
свой день рождения 12 января (см.: Там же.). В автобиографии 1949, на которую мы уже ссылались в прим. 3, Оксман также назвал датой своего рождения 5 января 1895 (см.: Пугачев, Динес 1995: 8).

Процитируем полностью копию метрического свидетельства, хранящегося в студенческом деле:

«Свидетельство. Дано сие в том, что по метрической книге о родившихся по городу Вознесенску евреях за 1895 г. под № 4 мужской графы значится акт следующего содержания: Тысяча восемьсот девяносто пятого года января 5-го дня у провизора Герша Оксмана и жены его Марьи родился сын, которому при обряде обрезания наречено было имя “Юлиан”. В чем подписью и приложением печати удостоверяю.

Г. Вознесенск 1895 года Января 8 дня. Вознесенский Городовой Раввин Врач А. Розен (М. П.).

Вознесенская городская управа на основании 1086 ст<атьи> IX т<ома> I ч<асти> зак<она > о сост<ояниях > издан<ия> 1876 г. удостоверяет, что изложенный в этом свидетельстве акт при сличении его с подлинным актом, записанным в метрической книге о родившихся евреях по г. Вознесенску 1895 г. под № $4<,>$ оказался тождественным.

16 июня 1912 года. По реестру № 1985. В метрической книге, хранящейся в Управе<,> имя жены значится “Марьям".

Городской голова Ф. Кухаренко.

Секретарь Аленин

Столоначальник В. Зотов

(М. П.) $\aleph^{17}$.

В вознесенскую гимназию, открытую в 1876 (см.: [Гельбке] [1912]: 85), Юлиан Оксман поступил девяти лет, в январе $1904^{18}$. Судя по

17 Д. 63266. Л. 30. Копия. Полное имя матери - Мария Яковлевна Оксман (урожд. Эпштейн; 1873-1969), см.: Чудакова, Тоддес 1988: 97. Однако в документе из студенческого дела, который приводится ниже, ее девичья фамилия передана как Энгилоф (см.: Д. 63266. Л. 29. Копия). Даты жизни М. Я. Оксман указываем по: Оксман 2008: 26, 153.

18 См.: Д. 63266. Л. 6. 
тому, что он «при отличном поведении обучался по 14 июня 1912 года и кончил полный восьмиклассный курс» ${ }^{19}$, он был принят в приготовительный класс. Окончив гимназию с единственной четверкой по математике ${ }^{20}$ и получив из-за нее не золотую, а серебряную медаль ${ }^{21}$, Оксман уехал в Германию. 19 ноября 1912 (по новому стилю) он записался на философский факультет Гейдельбергского университета ${ }^{22}$. Свидетельство об окончании (Abgangs-Zeugnis) зимнего семестра датировано 8 марта 1913 по новому стилю (см. илл. 1). В Боннский университет, также на философский факультет, Оксман записался 3 мая $1913^{23}$, на летний семестр, который продолжался до 23 июля ${ }^{24}$. Он выбрал трех профессоров - двух историков-медиевистов и одного философа - и начал слушать их с 8 мая ${ }^{25}$. Записи о лекциях в студенческой книжке сделаны рукой Оксмана, в одной из записей допущена ошибка: вместо »Friedrich der Großе« стоит »Friedrich den Grossen«.

Профессор Алоис Шульте (Aloys Schulte, 1857-1941), к которому записался Оксман, читал курс по истории Германии от Вестфальского мира (1648) до начала правления Фридриха Великого (1740) и курс по источниковедению средних веков. За слушание первого курса Оксман уплатил 18 марок $^{26}$, второй читался бес-

\footnotetext{
19 Там же.

20 «Про учителя, который снизил ему на экзамене отметку, сказал гневно: “Я ему руки не подам!”, - вспоминала вдова Оксмана (Чудакова, Тоддес 1988: 98). Преподавателем математики в вознесенской гимназии был Николай Владимирович Вережников, см.: [Гельбке] [1912]: 85. Точно так же Тынянов, получив четверку по латыни, лишился права на золотую медаль, см.: Сухих, Шубин 1989: 45, 46. Латынь в Псковской гимназии преподавал директор Артур Генрихович Готлиб, см.: [Гельбке] [1912]: 7.

21 В аттестате отмечены его отличные успехи «в науках, в особенности же в историкофилологических» (Д. 63266. Л. 6 об.). Учителем русского языка был Федор Сергеевич Сунгуров, историю вел Иван Иванович Грищенко, см.: [Гельбке] [1912]: 85.

22 См. имматрикуляционную книгу: [http://digi.ub.uni-heidelberg.de/diglit/matrikel1907 /0422/scroll?sid=0236c3561573ad8e42984b24d5b9b23b].

23 См.: [http://digitale-sammlungen.ulb.uni-bonn.de/periodical/pageview/830184].

24 См. в справке об эксматрикуляции: «Ausgeh<en> 23/7 1913» (илл. 4). В этот день Оксман был в Лейпциге, в российском консульстве, см. ниже.

25 См. даты и подписи профессоров в студенческой книжке - Anmeldebuch (илл. 2 и 3).

2618 марок равнялись примерно 9 рублям, см. в воспоминаниях другого русского студента, Ф. А. Степуна, приехавшего в Гейдельберг в 1902: «Снятая мною за 13 марок,
} 
платно (по всей вероятности, это были семинарские занятия). Профессор Вильгельм Левизон ${ }^{27}$ читал лекции по истории средних веков (вторая часть) и по истории возникновения (Anfänge) в Италии государства, находившегося под властью римского папы, Папской области (Kirchenstaate). Первый курс тоже стоил 18 марок, второй был бесплатным. На лекции по эстетике Оксман записался к основателю вюрцбургской школы «психологии мышления» профессору Освальду Кюльпе (Oswald Külpe, 1862-1915), чьи труды по философии переводились на русский язык в начале XX века. Из Бонна Оксман уехал, по-видимому, после 1 августа 1913 (нового стиля $)^{28}$.

О своем учении в Германии в 1912-1913 учебном году Оксман сообщил С. А. Венгерову, который, приводя список участников Пушкинского семинария, написал о студенте: «Раб<отал> по философии и ист <ории > сред<них > веков в Гейдельберге и Бонне <...» (Пушкинист 1916б: 291)29. Однако Оксман не упомянул об этом факте ни в curriculum vitae, приложенном к письму И. А. Шляпкину от 7 мая 1917, ни в автобиографии $1949^{30}$ (что для этого года вряд ли покажется удивительным), ни в прошении на имя ректора С.-Петербургского университета ${ }^{31}$ от 1 августа 1913 (старого стиля).

т. е. за 6 руб. 50 к. комната (эта цена включала утренний кофе, освещение и уборку) <...» (Степун 2000: 78).

27 См. о нем: Becher 2010.

28 См. свидетельство об эксматрикуляции (илл. 4). За присланные файлы, содержащие сведения о датах и прослушанных курсах, мы признательны архивистке Боннского университета Rebecca Bender и преподавательнице Бременского университета Алле Койтен (Keuten). Мы глубоко благодарны Г. Г. Суперфину, без чьего доброжелательного содействия получение информации оказалось бы невозможным.

29 Во второй раз несколько измененная информация об этом появилась в печати в 1934: «Специализировался по источниковедению, текстологии и истории, занимаясь в Гейдельбергском и Боннском университетах» (ЛЭ 1934, VIII: 269-270).

30 «По окончании Вознесенской гимназии поступил на историко-филологический факультет Петербургского университета <...> (Пугачев, Динес 1995: 8).

31 Эрвин Давидович Гримм (1870-1940), ректор С.-Петербургского университета в 1911-1918, доктор всеобщей истории, профессор по кафедре всеобщей истории, см.: Отчет 1914: 1, 3-я паг. Мандельштам, подавая в 1911 прошение на романо-германское отделение историко-филологического факультета, см.: Мандельштам 2009-2011, 3: 580 (опубликовано с пропуском трех слов), также ни звуком не обмолвился о том, 


\section{«От сына провизора}

Юлиана Григорьевича Оксмана

\section{Прошение.}

Желая для продолжения образования поступить на Историкофилологический факультет, имею честь покорнейше просить Ваше Превосходительство сделать зависящее распоряжение о принятии меня в число студентов первого курса С.-Петербургского Университета на основании прилагаемых при сем документов с копиями, а именно: 1) аттестат зрелости за № 716,2$)$ кондуитный список фармацевтической деятельности отца моего, 3) свидетельство о рождении за № 10,4$)$ свидетельство о крещении с переводом, заверенным консулом г. Лейпцига, 5) свидетельство о приписке к призывному участку за № 5757, 6) квитанция почтовой конторы о принятии прошения на имя херсонского Губернатора о выдаче свидетельства о благонадежности, 7) четыре фотографические карточки, засвидетельствованные официальным порядком.

Установленный взнос в пользу университета за текущее полугодие при сем высылаю, приложив соответствующую квитанцию 32 .

Сын провизора

Юлиан Оксман

Местожительство имею в Вознесенске (Хер<сонской> губ<ернии>) по Манежной улице.

1 августа 1913 г.» ${ }^{33}$.

что записывался в Сорбонну, см.: С<труве> 1990 (III): 255-257 и несколько месяцев слушал лекции в Гейдельбергском университете, см.: Бейер 1988: 222-225. Причина, по-видимому, лежит в том, что ни Оксман, ни Мандельштам не сдавали никаких экзаменов за время обучения в Германии. В противном случае абитуриент сообщал, что он ранее учился в заграничных учебных заведениях, см., например, прошение А. А. Гвоздева, будущего театроведа, поступившего в 1908 на романо-германское отделение историко-филологического факультета: «Свидетельство о прослушанном в продолжение шести семестров полном курсе философии вместе со свидетельством о посещении практических занятий (5) по философии и о прослушанных лекциях по романской филологии, естественным наукам и общеобразовательным предметам. Все в университетах гор<ода> Мюнхена (4 сем<естра>) и Лейпцига (2)» (ЦГИА СПб. Ф. 14. Оп. 3. Д. 53292. Л. 1).

32 Взнос в двадцать пять рублей вносился студентами каждый семестр, помимо платы за лекции.

33 Д. 63266. Л. 3. 
Свидетельство о благонадежности Оксмана было выписано еще 26 июня (то есть он запросил свидетельство, находясь в Германии) и с грифом «секретно» отправлено на имя ректора С.-Петербургского университета:

«М. В. Д.

Херсонский губернатор.

По канцелярии.

Стол 3.

Июня 26 дня 1913 г.

№ 21316.

Г. Херсон.

Секретно.

Ректору Императорского С.-Петербургского Университета.

Согласно ходатайству Юлиана Оксмана о выдаче ему свидетельства о благонадежности для пр<е>дставления в Императорский С.-Петербургский Университет при поступлении уведомляю Ваше Превосходительство, что Юлиан Оксман за время жительства во вверенной мне губернии и за границей в течении <sic! - М. C.> свыше пяти лет ни в чем предосудительном не замечен<,> под судом и следствием не состоял и не состоит и к делам политического характера не привлекался.

За Губернатора

Управляющий Казенною Палатою < подпись >

Правитель Канцелярии $<$ подпись $>»^{34}$.

За два с половиной месяца до подачи Оксманом прошения о приеме, 13 мая 1913, декан историко-филологического факультета С.-Петербургского университета Ф. А. Браун ${ }^{35}$ подал ректору следующее

\footnotetext{
34 Там же. Л. 5 - Л. 5 об.

35 Федор Александрович Браун (1862-1942, в эмиграции), германист, магистр истории западноевропейских литератур, декан историко-филологического факультета с 21 января 1912, исполняющий должность ординарного профессора по кафедре романо-германской филологии (см.: Отчет 1914: 3, 3-я паг.). В 1920 он уехал из России, в 1922-1932 преподавал в Лейпцигском университете. В шутливом стихотворении «Пастораль», сочиненном В. В. Гиппиусом, М. Л. Лозинским и О. Э. Мандельштамом
} 
«Представление.

Имею честь представить Вашему Превосходительству, что историко-филологический факультет в собрании своем 11 сего Мая постановил установить комплект приема на факультет в 1913/14 уч. году в 500 человек.

Декан Ф. Браун» ${ }^{36}$.

Как следует из обращения ректора к попечителю Петербургского учебного округа от 24 мая 1913, кроме 500 человек на историкофилологический факультет, университет предполагал принять 800 человек на физико-математический факультет (из них 450 - на математический разряд и 350 на естественный разряд), 1200 - на юридический факультет и 150 - на факультет восточных языков ${ }^{37}$, итого - 2650 человек. В числе этих 2650 студентов не должно было быть ни одного еврея. Тем же 13 мая, что и представление Брауна ректору, датируется протокол заседаний Совета императорского С.-Петербургского университета:

«Доложены Совету к сведению условия приема в студенты на 19131914 учебный год, причем ректор сообщил Совету, что в текущем году не представляется возможным зачислять в студенты лиц иудейского вероисповедания, так как общее количество студентовиудеев по отношению к общему числу всех студентов превышает 3\%» (Протоколы 1915: 109) $)^{38}$.

15 октября 1912, фигурирует «рыцарь Университета Браун», см.: Мандельштам 20092011, 1: 345, 717. Лекции Брауна по истории западноевропейских литератур Оксман посещал, учась на пятом и шестом семестрах, осенью 1915 и весной 1916 (см.: Д. 63266. Л. 22 об. - 23). Этот же курс Брауна осенью 1910 и весной 1911 слушал Б. М. Эйхенбаум, см.: Сальман 2014: 455. Мандельштам слушал лекции Брауна по введению в германскую филологию и сдал ему экзамен по этому предмету, подробнее см.: Сальман 2010: 459, 467, 469.

36 ЦГИА СПб. Ф. 14. Оп. 1. Д. 10730. Л. 3.

37 См.: Там же. Л. 4. В печатных протоколах приводится число 450 - для естественного разряда и 350 - для математического, см.: Протоколы 1915: 109.

38 Среди еврейских абитуриентов, не допущенных в университет в 1913, оказался и будущий поэт Виктор Моисеевич Тривус (13 июля 1896-1920?). Его родители - Ева Лейбовна (урожд. Крепс) и Моисей Лейбович Тривус, см.: ЦГИА СПб. Ф. 14. Оп. 3. Д. 65161. Л. 4. Копия. В литературе фигурирует неверная дата рождения - 1895, см.: Шруба 
Сведения об этом решении университетского Совета не сразу попали в печать. На заседании рассматривалось несколько вопросов, и петербургская газета «Русская молва» сообщила вначале, что ректор доложил Совету профессоров «о поступившем от петербургской городской думы предложении обсудить вопрос о возможности учреждения при университете медицинского факультета. <...> Совет постановил отложить рассмотрение его на осень $<\ldots>»^{39}$. Однако спустя четыре дня, 17 мая, газета писала:

\section{«В университете.}

В последнем заседании правления спб. $<$ sic! - M. C.> университета рассматривался вопрос относительно приема в университет лиц иудейского вероисповедания. Выяснилось, что в 1913-1914 учебном году приема лиц иудейского вероисповедания быть не

2004: 425. Отец - юрист, публицист, член редколлегии журнала «Восход». Виктор Тривус окончил гимназию при Училище евангелическо-лютеранской церкви Св. Екатерины в 1913, см.: Там же. Л. 3 об. Копия. Как он сам писал в 1914 в прошении ректору о приеме, он два семестра пробыл на философском факультете Базельского университета: «<...> я не мог поступить в русский университет за отсутствием вакансий для евреев» (Там же. Л. 2). Принятый в 1914 на классическое отделение историко-филологического факультета, см.: Там же. Л. 12, он, на правах вольноопределяющегося, с 4 августа 1916 находился на действительной военной службе, см.: Там же. Л. 8. Л. 9. В мае 1917 был юнкером «2-го взвода I роты III ей Петергофской школы прапорщиков» (Там же. Л. 23). Погиб на Гражданской войне, участвуя в польском походе Красной армии. Член университетского «Кружка поэтов», ядро которого, по воспоминаниям В. А. Рождественского, «составляли мы с Георгием Масловым, Виктор Тривус, Анна Регатт <псевдоним Е. М. Тагер. - M. С.>, Ник. Оцуп» (Богомолов 2010: 663, см. также c. 503). Участник поэтического сб. «Арион» (1918), см.: Струве 1979: 21. Новейшую публикацию его стихов см.: Тименчик 2010: 169-181. «Первоначальный вариант стих. “Бонн” был поднесен автором Ю. Г. Оксману 1 мая 1916 г.» (Там же: 181). Георгий Владимирович Маслов (1895-1920) учился в университете в 1913-1916, поэт, активный участник венгеровского семинария, дружил с Оксманом, Тыняновым. Умер от тифа, служа рядовым в армии адмирала Колчака. Елена Михайловна Тагер (1895-1964), поэтесса, прозаик, автор воспоминаний о Блоке и Мандельштаме, жена Маслова. Арестованная в первый раз в 1922, была в ссылке в Архангельске. Вторично арестована по ленинградскому «писательскому делу» в 1938, пробыла 10 лет на Колыме (там встретилась с Оксманом), потом была отправлена в ссылку. С 1954 жила в Саратове у дочери от второго брака, М. Н. Смирновой (урожд. Авдеевой; выступала в печати под фамилией матери), реабилитирована в 1956, после чего смогла вернуться в Ленинград.

39 Русская молва. 1913. 14 (27) мая. № 150. С. 2. 
может <жирный шрифт в источнике. - М. С.>, т. к. процентная норма исчисляется в отношении числа всех находящихся в университете студентов, число же находящихся в университете евреев превышает законную норму» ${ }^{40}$.

По всей вероятности, Оксман вскоре узнал об этом решении и незадолго до возвращения в Российскую империю (прошение ректору, отправленное из Вознесенска, датировано 1 августа старого стиля), 13 июля 1913 по новому стилю, крестился.

«Копия.

Перевод с немецкого.

Свидетельство.

Господин Юлиан Оксман, студент филологии, проживающий в настоящее время в городе Бонне, родившийся 5-го Января 1895 года в городе Вознесенске, в России, сын Григория (провизора в Вознесенске) и Марии, урожденной Энгилоф<,> супругов Оксман, после полученного наставления, приобщен мною сегодня к евангелической церкви.

Бонн 13 июля 1913 г. (подп.) Пастор Кремерс.

(М. П.)

За верность перевода

присяжный переводчик при

королевских судах в Лейпциге

(М. П.) Виктор Армгауз

№ 935. Прич<итается> 3 р. (нрзб.) $=6 \mathrm{~m} .50$ pf. $^{41}$

Императорское Российское Консульство

в Лейпциге удостоверяет подлинность предстоящих подписи и печати Присяжного Переводчика Виктора Армгауза в Лейпциге.

Лейпциг 10/23 Июля 1913 года

Управляющий Консульством

(М. П.) М. Никольский» ${ }^{42}$.

40 Там же. 17 (30) мая. № 153. С. 4.

416 марок 50 пфеннигов.

42 Д. 63266. Л. 29. Копия. 
9 сентября 1913 новоиспеченный студент обязался в течение первого семестра «сдать греческий язык в объеме гимназического курса» ${ }^{43}$ (в вознесенской гимназии греческий не преподавался) и спустя три месяца, 10 декабря 1913, выдержал его у Е. М. Придика ${ }^{44}$.

11 сентября 1913 Оксман получил матрикул и начал учиться на славяно-русском отделении историко-филологического факультета Петербургского университета ${ }^{45}$. В неоднократно упомянутой автобиографии 1949 Оксман писал, что «слушал лекции по двум отделениям - историческому и славяно-русскому <...> (Пугачев, Динес 1995: 8). В заметках 1960-х ученый вспоминал: «Некоторое время я занимался русской историей, работая в семинаре М. В. Клочкова» ${ }^{46}$ (Зайцев 1990: 527). Просеминарий М. В. Клочкова «Общественный быт второй половины XVIII ст<олетия> по запискам и мемуарам современников» (Обозрение 1913: 19) Оксман посещал в первом семестре и начале второго, а 28 марта 1914 получил по нему зачет ${ }^{47}$. Из исторических дисциплин Оксман слушал в первом и втором семестрах курс по истории церкви (его читал И. Д. Андреев $)^{48}$,

43 Там же. Л. 4. Что касается объема, то в гимназии в течение четырех лет (с третьего по шестой класс, когда изучался греческий) ученики успевали прочесть несколько глав из «Анабасиса» Ксенофонта и глав тридцать из «Киропедии» или «Греческой истории» того же Ксенофонта. Или столько же глав из «Истории» Геродота и одну или две песни из «Одиссеи» (см.: Гуревич 1899: 130-131).

44 Там же. Л. 15 об. - 16. «Для лиц, не обучавшихся в гимназии греческому языку или желающих в нем усовершенствоваться, при факультете ежегодно организуется элементарное преподавание его» (Обозрение 1912: 35). На экзамене требовалось чтение à livre ouvert греческого автора (см.: Там же). Евгений Мартынович Придик (18651935), магистр классической филологии, приват-доцент, см.: (Отчет 1914: 20, 3-я паг.).

45 М. А. Фролов безосновательно относит поступление Оксмана в Петербургский университет к 1912, утверждая также, что он вернулся из Германии в сентябре 1913, см.: Фролов 2014: 111.

46 Михаил Васильевич Клочков (1877-1952) - магистр истории, окончил историкофилологический факультет Дерптского университета, был приват-доцентом в Петербургском университете, преподавал на Высших женских (Бестужевских) курсах. Подробнее см.: Чухлий 2010: 265-274. [http://dspace.univer.kharkov.ua/bitstream/ 123456789/7551/2/Chuxlii_S.A.pdf] О Клочкове см. в мемуарах историка С. Г. Пушкарева, который занимался у него в 1916 в Харьковском университете: Пушкарев 1999: 46-48.

47 См.: Д. 63266. Л. 18 об. - 19. Л. 20 об. Л. 21.

48 См.: Там же. Л. 20 об. Л. 21. Иван Дмитриевич Андреев (1867-1927), окончил Московскую духовную академию. В 1907-1924 профессор истории церкви Петербургского университета. 
который стал обязательным для студентов славяно-русского отделения в $1909^{49}$. Наконец, на общий курс русской истории Оксман записывался к С. В. Рождественскому ${ }^{50}$ осенью 1914 и весной $1915^{51}$. Этот предмет был также обязателен на всех четырех отделениях историко-филологического факультета, то есть не только на историческом, но и на классическом, романо-германском и славянорусском (заметим в скобках, что в число полукурсовых испытаний для студентов классического и исторического отделений входила история русской словесности). Экзамен по русской истории Оксман сдал «весьма удовлетворительно» А. Е. Преснякову 7 сентября $1915^{52}$. Ни на какие другие предметы исторического отделения Оксман не записывался, в его матрикуле фигурирует только славяно-русское (оно же словесное) отделение, как и в выпускном свидетельстве:

«Предъявитель сего Юлиан Григорьевич Оксман евангелическолютеранского вероисповедания, сын провизора<,> родившийся 5 Января 1895 года <...> принят был в число студентов Петроградского Университета в Сентябре 1913 года и зачислен на Историко-Филологический Факультет (на Словесное отделение) $<\ldots>$ подвергался испытанию из немецкого языка ${ }^{53}<\ldots>$ имеет восемь зачтенных полугодий. <...> 29 Марта 1917 года» ${ }^{54}$.

49 Б. М. Эйхенбаум писал родителям 20 марта 1909: «Есть у нас кое-какие нововведения: прибавлена русская история < .. > прибавлена история русской церкви» (Кертис 2004: 282). 50 Сергей Васильевич Рождественский (1868-1934), в 1891 окончил петербургский университет, с 1897 магистр русской истории, приват-доцент. В 1903-1913 член Ученого комитета министерства народного просвещения, см.: Протоколы 1915: 187. 29 апреля 1912 защитил докторскую диссертацию, см.: Протоколы 1914: 85, тогда же опубликованную: «Очерки по истории систем народного просвещения в России в XVIII-XIX вв.» Т. 1. (СПб., 1912). Чл.-корр. АН (1920). С 1925 помощник директора БАН С. Ф. Платонова. Был арестован в 1929 по «Академическому делу», умер в ссылке.

51 См.: Д. 63266. Л. 21 об. Л. 22.

52 См.: Там же. Л. 16 об. - 17. Александр Евгеньевич Пресняков (1870-1929), приватдоцент, ученик С. Ф. Платонова. Член-корр. АН с 1920.

53 Немецкий язык Оксман сдал «весьма удовлетворительно» через полтора месяца после поступления в университет, 1 ноября 1913, Ф. Е. Беттаку, см.: Там же. Л. 15 об. - 16. Фридрих Евгеньевич Беттак имел диплом первой степени Петербургского университета, в службе и ведомстве находился с 1 сентября 1903, см.: (Отчет 1914: 13, 3-я паг.).

54 Д. 63266. Л. 9. В письме к историку А. С. Нифонтову от 15 декабря 1963 Оксман ошибочно сообщал: «зачетное («выпускное») свидетельство получил еще до революции, 


\section{В письме к Г. П. Струве (ноябрь 1962) Оксман писал о Мандель- штаме:}

Я хорошо помню О. Э. по университету, но встречал его очень редко, на некот<оры>х экзаменах, на вечерах поэтов ${ }^{55}$, в знаменит <ом> унив<ерситетск>ом коридоре. $<\ldots>$ многие экз<амен>ы мы сдавали вместе (философ<ские> предметы, ист<ория > греч<еской> лит<ератур>ы). Помню, как он жалко провалился на эк<замен>е у проф. Г. Ф. Церетели ${ }^{56}$ в 1916 г. - от волнения у него дрожали руки и ноги, он заикался, чуть не плакал. Он не мог назвать ни одной комедии Менандра, хотя знал, что Церетели автор монографии об этих комедиях. Заглянув в его зачетную книжку, я убедился, что О. Э. не «сдал» самых основных обязат<ельны>х курсов, у него почти не было и семинарских зачетов (цит. по: Флейшман 1987: 22-23).

При сопоставлении матрикулов обоих студентов оказалось, что Оксман и Мандельштам вместе сдали два экзамена: 24 апреля 1914 введение в философию И. И. Лапшину ${ }^{57}$ и 5 сентября 1916

осенью 1916 г.» (Богаевская 1990: 100).

55 «<..> из наших старших товарищей читали свои стихи Гумилев, Осип Мандельштам, М. <Л.> Лозинский, В. <В.> Гиппиус, а из сокурсников Георгий Маслов, Всеволод Рождественский <...> В. Тривус, Д. П. Якубович, Д. <И.> Выгодский», - вспоминал Оксман (Чудакова, Тоддес 1984: 92). 13 ноября 1913 в романо-германском кружке «состоялся "Вечер стихов" при участии поэтов Гумилева, Мандельштама, Г. Иванова, Пяста, Парнока, Гиппиуса и Бахтина» (Отчет 1914: 384). Парнок - Валентин Яковлевич Парнах (наст. фамилия Парнох, в цитируемом издании допущена опечатка; 14 июля 1891-1951, дату рождения приводим по свидетельству о рождении, см.: ЦГИА СПб. Ф. 14. Оп. 3. Д. 57235. Л. 9. Словарь приводит дату 15 июля, см.: Русские писатели 1999, 4: 531) в это время - студент юридического и одновременно историко-филологического факультета (романо-германское отделение). Николай Михайлович Бахтин (1894-1950) был студентом славяно-русского отделения.

56 Григорий Филимонович Церетели (1870-1938), профессор Петроградского университета по кафедре классической филологии с 6 октября 1914, см.: Отчет 1915: 98. 2 февраля 1914 защитил докторскую диссертацию «Новые комедии Менандра», см.: Протоколы 1916: 6. С декабря 1917 член-корр. АН. Арестовывался в 1918, в ноябре 1919 и в 1931. Профессор Тбилисского университета, он был в конце 1937 «публично объявлен Берией в числе реакционных и уже уничтоженных профессоров» (Перченок 1995: 208), арестован в начале 1938 , подвергнут пыткам и убит.

57 См.: Д. 63266. Л. 15 об. - 16; Сальман 2010: 465; 468. Иван Иванович Лапшин (18701952) окончил Петербургский университет в 1893, с 1897 - приват-доцент, в 1906 за 
историю римской литературы Ф. Ф. Зелинскому ${ }^{58}$, оба получили высшую оценку - «весьма удовлетворительно». Экзамен по истории древнегреческой литературы Оксман выдержал у Церетели «весьма удовлетворительно» 29 апреля $1916^{59}$, очевидно, в этот же день и Мандельштам пытался его сдать ${ }^{60}$ (из матрикула Мандельштама известно, что в 1915-1916 учебном году он записался на курс лекций Г. Ф. Церетели о «Геракле» Еврипида, а осенью 1916 - на лекции по истории древнегреческой литературы ${ }^{61}$. Что касается «основных обязательных курсов», о которых пишет Оксман, то из шести требуемых экзаменов Мандельштам сдал пять (кроме факультетского - не путать с поверочным - экзамена по греческому языку). Из шести специальных экзаменов по романо-германскому отделению Мандельштам выдержал четыре: введение в романскую и германскую филологию, историю римской литературы, новую историю, русскую историю (не сдал историю греческой литературы и один из германских языков). Из четырех просеминариев, в которых должен был участвовать студент романо-германского отделения, Мандельштам получил зачеты по двум: по одному из романских языков (поэт выбрал староиспанский) и по одной из романских литератур (творчество Клемана Маро) ${ }^{62}$. И Оксман и Мандельштам, оба, хотя и в разные дни, сдали в 1916 экзамен по древней философии И. И. Лапшину ${ }^{63}$. Что касается лекций, то

книгу «Законы мышления и формы познания» ему была присуждена докторская степень вместо магистерской, см.: Протоколы 1915: 183, 184, профессор по кафедре философии со 2 декабря 1913, см.: Отчет 1914: 7, 3-я паг. 16 ноября 1922, несмотря на заступничество А. М. Калмыковой и А. В. Луначарского, был выслан за границу вместе с Л. П. Карсавиным, Н. О. Лосским и др. Жил в Чехословакии, «принимал активное участие в деятельности учебных заведений для эмигрантской молодежи» (Высылка 2005: 38, 263, 264, 458).

58 См.: Д. 63266. Л. 16 об. - 17; Сальман 2010: 468. Фаддей Францевич Зелинский (1859-1944, в эмиграции), доктор греческой словесности, профессор по кафедре классической филологии, см.: Отчет 1914: 13, 3-я паг.

59 Д. 63266. Л. 16 об. - 17.

60 Дата отсутствует в летописи жизни и творчества поэта, см.: Мандельштам 2014.

61 См.: Сальман 2010: 467, 468.

62 Подробнее см.: Сальман 2010: 463-469.

63 Д. 63266. Л. 18 об. - 19; Сальман 2010: 468. 
осенью 1914 оба записались на курс Ф. Ф. Зелинского о греческих лириках ${ }^{64}$ и на курс о Катулле у А. И. Малеина ${ }^{65}$. Весной 1915 Оксман и Мандельштам записывались на лекции Малеина о Тибулле ${ }^{66}$, а осенью 1915 г. и весной 1916 - на историю римской литературы у Зелинского ${ }^{67}$.

Нам уже довелось писать о дате знакомства Оксмана с Тыняновым, которое состоялось не в годовщину смерти Толстого, 7 ноября 1913, как вспоминал Оксман (см.: Чудакова, Тоддес 1984: 91-92), а в день оправдания Менделя Бейлиса, 28 октября 1913 (см.: Сальман 2014: 457-459). Здесь прокомментируем следующий мемуарный фрагмент: «С осени 1914 года приступил к чтению лекций и к ведению семинария по древнерусской литературе В. Н. Перетц $^{68}<\ldots>$ его грубые нападки на изучение русской литературы XIX в. вообще, и на пушкиноведение в частности, оттолкнули меня и моих ближайших друзей (Тынянов, Маслов, Комарович ${ }^{69}$ от приобщения к этому кладезю филологической науки <...» (Чудакова, Тоддес 1984: 93). Между тем осенью 1916 Оксман записался на лекции Перетца по истории русской литературы XVII в. и в просеминарий по церковнославянскому языку ${ }^{70}$. За весну 1917 в матрикуле есть записи к Перетцу на русскую литературу

\footnotetext{
64 Оксман вспоминал, что вместе с Тыняновым слушал этот курс Зелинского, см.: Чудакова, Тоддес 1984: 93, однако из матрикула Тынянова следует, что он на него не записывался, см.: Сальман 2014: 464, 496.

65 См.: Д. 63266. Л. 21 об. Сальман 2010: 465, 466. Александр Иустинович Малеин (1869-1938), доктор римской словесности, приват-доцент по кафедре классической филологии, см.: Отчет 1914: 19, 3-я паг. Чл.-корр. АН (1916). С 1924 по 1931 работал в БАН. Переводил Д. П. Карпини «История монгалов», Г. Рубрука «Путешествие в восточные страны», С. Герберштейна «Записки о московитских делах», Т. Мора «Утопия».

66 См.: Д. 63266. Л. 22. Сальман 2010: 466. Экзамен Малеину Мандельштам провалил 29 сентября 1915 (см.: Мандельштам 1990: 251) и пересдал 18 октября 1916 (см.: Сальман 2010: 468).

67 См.: Д. 63266. Л. 22 об. Л. 23. Сальман 2010: 467.

68 Владимир Николаевич Перетц (1870-1935), историк литературы, фольклорист, театровед, академик. Арестован по «Делу славистов» в 1934, умер в ссылке в Саратове. 69 Василий Леонидович Комарович (1894-1942, в блокаду) занимался Достоевским, Пушкиным, автор монографии «Китежская легенда» (1936).

70 См.: Д. 63266. Л. 23 об.
} 
XVII в., на славяно-русскую палеографию и в просеминарий по церковнославянскому языку ${ }^{71}$. Интересно, что у Оксмана возникло такое желание, ведь церковнославянским языком он занимался раньше - в просеминарии у Л. В. Щербы осенью $1914^{72}-$ и получил по нему зачет 11 апреля 1915 $5^{73}$. Тынянов записался к Перетцу весной 1915 на славяно-русскую палеографию, а осенью 1915 - на курс истории древнерусской литературы (см.: Сальман 2014: 465).

«Большое влияние оказали на меня в университетские годы лекции и семинары А. А. Шахматова, И. А. Шляпкина, Н. М. Лисовского $^{74}$ и Н. К. Пиксанова ${ }^{75}<\ldots>»,-$ вспоминал Оксман (Зайцев 1990: 527). Поступив в университет, он сразу записался к Шахматову на лекции о «Несторовой летописи» - так назван курс в матрикуле ${ }^{76}$ (см. также: Обозрение 1913: 11). В воспоминаниях о Тынянове Оксман подчеркнет: «<...> Ю. Н. особенно ценил Шахматова (мы с ним вместе прослушали его замечательный годовой курс о "Повести временных лет”)» (Чудакова, Тоддес 1984: 93). 10 сентября 1915 Оксман сдал Шахматову «удовлетворительно» экзамен по сравнительной грамматике славянских языков - единственная «тройка» в его матрикуле 77 , а в 1915-1916 учебном году слушал его курс по великорусской диалектологии ${ }^{78}$. За осень 1916 и весну 1917 в матрикуле находятся записи на лекции по русскому языку ${ }^{79}$, но поскольку в этом году Шахматов читал два курса («Очерк синтаксиса

\footnotetext{
71 См.: Там же. Л. 24.

72 См.: Там же. Л. 21 об. 9 сентября 1916 Оксман выдержал у Щербы «весьма удовлетворительно» необязательный экзамен по сравнительной морфологии индоевропейских языков, см.: Там же. Л. 18 об. - 19.

73 См.: Там же.

74 Николай Михайлович Лисовский (1854-1920), библиограф, автор указателя «Библиография русской периодической печати. 1703-1900» (1915). Зачислен в состав приват-доцентов по кафедре русского языка и словесности с 1 июля 1913, см.: Отчет 1914: 54. Подробнее см.: Русские писатели 1989-1999, 3: 366-367.

75 Николай Кириакович Пиксанов (1878-1969) занимался Грибоедовым, Белинским, Пушкиным, Тургеневым, в 1917-1921 преподавал в Саратовском университете.

76 См.: Д. 63266. Л. 20 об. Л. 21.

77 См.: Там же. Л. 16 об. - 17.

78 См.: Там же. Л. 22 об. Л. 23.

79 См.: Там же. Л. 23 об. Л. 24.
} 
русского языка» и «Очерк истории русского языка»), а кроме того, вел просеминарий по древнерусскому языку (по «Русской Правде») (см.: Обозрение 1916: 12), то невозможно с уверенностью сказать, что именно выбрал Оксман.

На первом курсе, осенью 1913, Оксман записался также на лекции С. А. Венгерова по истории русской литературы «от Белинского до наших дней» (Обозрение 1913: 11) и в Пушкинский семинарий $^{80}$. Получив зачет в венгеровском семинарии уже через полгода, 17 апреля $1914^{81}$, Оксман продолжал регулярно посещать его и выступать с докладами ${ }^{82}$. По-видимому, такие посещения были возможны без оплаты занятий, во всяком случае, Эйхенбаум писал Венгерову 10 ноября 1913: «Я, к сожалению, не имел времени для работы в вашем семинарии, но был частым слушателем» (Сальман 2014: 449).

Первая же публикация Оксмана «К вопросу о дате стихов Пушкина о старом доже и догарессе молодой» (1915) вызвала неожиданную реакцию, вот как ученый вспоминал об этом: «Она связана была с моей большой работой “Пушкин и художественная проза Э. Т. А. Гофмана”, а направлена была против некоторых приемов исследований Н. О. Лернера, опубликовавшего в том же "Русском библиофиле” статью “Стихи Пушкина о Марино Фальери”" очень небольшой статье <Лернера> было около 20 фактических неточностей и ошибок, но при подготовке своей статьи к печати я так искусно замаскировал ее полемическую часть, что Н. В. Соловьев, редактор “Русского библиофила", ее охотно напечатал (я получил за нее даже гонорар, из расчета 60 р<ублей> лист (первый мой литературный гонорар) - 15 руб<лей>), а сам Н. О. Лернер, оценив мою деликатность [и величественно учтя все мои

80 См.: Там же. Л. 20 об.

81 См.: Там же. Л. 18 об. - 19.

82 См.: Пушкинист 1916а: 287-289. Здесь опубликована роспись занятий в Пушкинском семинарии за 1913-1915. Библиограф А. Г. Фомин, бывший в юности секретарем Венгерова, вспоминал: «Очень характерным для семинария было то, что в нем принимали участие бескорыстно многие студенты-филологи, уже имевшие зачеты и не заинтересованные в получении их, и даже студенты других факультетов - юристы и естественники» (Фомин 1922: XVII).

83 См.: Лернер 1913: 25-31. 
поправки, разумеется, без указания источника, при перепечатке своей статьи, прислал], выразил желание со мной познакомиться и затем в течение долгого времени относился ко мне [необычно] с некоторой снисходительной благосклонностью, зато Юрий Ник<олаевич> Тынянов долгое время рвал и метал, не прощая мне этой детской дипломатии. Он, как и многие другие, старые и молодые, пушкинисты, очень не любил Н. О. Лернера - не столько за его работы, сколько за претензии на монополию положения суперарбитра в вопросах пушкиноведения, за недоброжелательный глумливый характер его печатных и устных отзывов о новых книгах, - литературное кредо которого, как рецензента всех новых книг по пушкинистике, сводилось к формуле заплечных дел мастеров: “Берегись, ожгу!” (Оксман 2005: 170-171) $)^{84}$.

По всей вероятности, Оксман смог напечататься в журнале благодаря рекомендации профессора Шляпкина, большого книжника, знавшего редактора Н. В. Соловьева, владельца антикварного книжного магазина и автора двухтомной биографии А. А. Воейковой (в девичестве Протасовой), которой посвящено стихотворение В. А. Жуковского «Светлана». Шляпкин и сам публиковался в журнале, см., например, его «Заметки об А. И. Полежаеве» (Русский библиофил. 1913. № 3. С. 94-96). В четырехстраничной заметке темпераментный двадцатилетний студент сделал четыре отнюдь не замаскированных замечания Лернеру: “"1822” без всякой мотивировки принят в “Трудах и днях Пушкина” <...> ввести в его работу незначительный корректив <..> по странному недосмотру утверждает Лернер <..> Н. О. Лернер подкрепил, однако, это соображение очень неудачно <...>» (Оксман 1915: 90, 91, 92).

В 1916 вышел второй выпуск «Пушкиниста»- сборника, где публиковались работы участников венгеровского семинария, на него появилось несколько рецензий, в которых упоминалась и статья Оксмана «Программа драмы А. С. Пушкина о паписсе Иоанне (к

84 Об отношениях Оксмана с Лернером см. в его очерке «Николай Осипович Лернер» и во вступительной статье публикатора С. И. Панова (Оксман 2005: 164-214). По теме «Тынянов и Лернер» см. статью Тынянова «Мнимый Пушкин» (1922, опубл. в 1977) и комментарий Е. А. Тоддеса: Тынянов 1977: 78-92; 421, 426-429. 
истории недовершенного замысла)» (см.: Оксман 1916: 258-268). Если В. Я. Брюсов просто назвал статью дельной (см.: Брюсов 1916: 81), то рецензент филологического издания отметил как сильную сторону статьи ее источниковедческий компонент: автор «только намечает возможную родственность паписсы с типами пушкинских женщин, но не доказывает этого наглядно и не привлекает для сравнения всех произведений Пушкина. < ..> главная заслуга автора разбираемого доклада заключается в том, что он привел исторические справки о главном действующем лице незавершенной драмы - паписсе Иоанне» (Вознесенский 1916: 178).

В 1917 публикуется статья Оксмана «Сюжеты Пушкина» (Оксман 1917: 73-95). Б. В. Томашевский, услышавший о ней еще до выхода издания, писал из действующей армии (он служил в инженерностроительной дружине) М. К. Клеману ${ }^{85}$ в длинном письме от 3 ноября - 21 декабря 1916, посланном с оказией: «Приехать в Петроград раньше конца войны я не мечтаю, так что мне не удастся принять участия в ваших Пушкинских и стиховедческих кружках ${ }^{86}$. Передайте от меня привет их участникам, если найдутся там мои знакомцы. Не сообщите ли мне о ходе занятий в этих кружках. Что поделывает семинарий по Пушкину и тому подобные учреждения. Между прочим<,> меня интересует вопрос о том, как встретила печать Пушкинист № 2-ой. Вероятно<,> в Семинарии знают. Не сообщите ли мне, как печать отозвалась об этом сборнике, и не было ли ценных критических статей. <..> Нельзя ли попросить у Оксмана оттисков его статей в Пушкине и его Современников $<$ sic! -

\footnotetext{
85 Михаил Карлович Клеман (1897-1942, в эвакуации), историк литературы, занимался Тургеневым, русско-французскими литературными связями. На историкофилологический факультет Петербургского университета поступил в 1915, участник Пушкинского семинария.

86 Историко-литературный студенческий кружок им. Пушкина открылся 5 декабря 1915, среди его учредителей были, в частности, С. М. Бонди, М. К. Клеман, Г. В. Маслов, Оксман, который в 1916-1917 выступил в нем с четырьмя докладами: о Пушкине и Арно; «Кровавый бандурист» - новые страницы Гоголя; о несостоявшемся журнале В. В. Измайлова «Современник»; о цензурной истории текстов Полежаева, см. перечень докладов, составленный Бонди, в предисловии Венгерова: (Венгеров 1918: IX). Bсе доклады были впоследствии опубликованы, см.: Богаевская, Черных 1997: 327, 328, 329.
} 
M. C.>. Меня его статьи очень интересуют, а иметь когда-нибудь ожидаемый № Пушкин и е<го $>$ С<овременники> в этой земной жизни я не надеюсь, а на том свете, боюсь, интересы будут настолько иные, что весь Пушкинизм утеряет свое значение» ${ }^{87}$. Любопытно, что имя Тынянова Томашевский впервые услышал от Клемана, которому он писал в ответном письме от 13 февраля 1917: «<..> занятия пушкинскими рукописями - чрезвычайно оздоровляют человека и исправляют взгляд на него. <..> Состав комиссии (мне неизвестны <..> жена Маслова ${ }^{88}$ и некто, чьей фамилии я не разобрал: перерисовываю Тынсыов) ручается за добросовестность» ${ }^{89}$.

Одно из последних (если не последнее) выступлений Оксмана в венгеровском семинарии состоялось уже после окончания им университета, осенью 1917. М. К. Клеман, отвечая на письмо Н. К. Пиксанова от 24 января 1918, в котором тот просил известить его «о себе, о Венгерове <...> об Оксмане, о Белинском, о Тургеневе, обо всем» ${ }^{90}$, писал:

87 РО ИРЛИ. Ф. 84. Ед. хр. 374. Л. 1 об. Л. 2. Другой фрагмент письма цитировался в статье: Измайлов 1960: С. 8-9. В этом же выпуске XXVIII «Пушкин и его современники» напечатана статья самого Томашевского «Заметки о Пушкине». Критический отзыв Томашевского об одной из трех вошедших в публикацию 1917 оксмановских заметок «К литературной истории стихов Пушкина “К***” (“Счастлив, кто близ тебя, любовник упоенный...”)» см.: Томашевский 1923: 78. К вопросу об отношениях между двумя учеными см.: Устинов 1994: 513-514; Гришунин 1999: 3-17, особенно 11. Приведем как пример пикировки: говоря о датировке пушкинской оды «Вольность», Оксман заметил, что «"политические прокламации не пишутся для письменного стола”, - Б. В. Томашевский позволил себе ироническую реплику: "Видно, Вы имеете личный опыт в таком деле...” (Там же: 13). Воспользуемся случаем, чтобы исправить ошибочную датировку в опубликованной А. Л. Гришуниным переписке Оксмана с Чуковским. Письмо Оксмана № 27, написанное, по предположению публикатора, весной 1956 (?), см.: Оксман - Чуковский 2001: 81, было написано ранее 13 июля 1955. Этим числом датировано письмо Е. М. Тагер, которая после ссылки жила в Саратове с неснятой судимостью, к Л. В. Шапориной: «Не помню, писала ли я Вам, что одновременно с письмом Федина я получила очень горячее и нежное письмо от К<орнея $>$ Ив<анови >ча и Коли, которые узнали мой адрес от Оксмана и сейчас же мне написали. Затем я получила от них “по праву дружбы” 1000 р., на которые немедленно оделась <...» (ОР РНБ. Ф. 1086. Ед. хр. 34. Л. 32). Коля - Н. К. Чуковский.

88 Е. М. Тагер.

89 РО ИРЛИ. Ф. 84. Ед. хр. 374. Л. 5.

90 РО ИРЛИ. Ф. 84. Ед. хр. 329. Л. 3. 
«<..> Университет хотя и открылся формально, но лекции протекали вяло. Я видел листы для записи в семинарии - все по два $<,>$ по три, много по четыре человека, и только у Семена Афанасьевича больше. Я принимал участие в одном Пушкинском семинарии. Состав весь целиком обновился, и пока еще только ознакамливается с Пушкиным, до сих пор было прочитано только три реферата - да и то один Оксманом - О “Розе” Пушкина, а другой мною - О тексте лицейских стихов ${ }^{91}<\ldots>$ Пушкинский кружок до Рождества заседал только два раза - Андрей Белый прочел доклад о “Ритмическом жесте” - распространил и популяризировал одну из глав своей статьи в первом томе “Скифов"92. Второе заседание было посвящено прениям, впрочем, в отсутствии $<$ sic! - M. C.> peферента ${ }^{93}$. После Рождества деятельность кружка несколько оживилась. Б. М. Эйхенбаум прочел доклад о “Мелодике лирического стиха", в котором доказывал наличность двух поэтических школ - ритмической и мелодической ${ }^{94}$. Для меня

91 Заметка Оксмана «Роза» включена в его статью «Сюжеты Пушкина. (Отрывочные замечания)», см.: Оксман 1922: 24-39. В этом же издании напечатана статья Клемана о лицейских стихах, см.: Клеман 1922: 1-12. Его выступление следует отнести к ноябрю 1917, см.: РО ИРЛИ. Ф. 84. Ед. хр. 425. Л. 1.

92 Об этом докладе, состоявшемся 14 октября 1917, Оксман с восторгом писал жене 15 октября 1917, см.: Зайцев 1990: 529; тот же фрагмент письма цитировался в: Жирмунская, Эйхенбаум 1988: 327. Оксман запомнил это выступление, хотя и позабыл точную дату доклада. Путая строчки Тютчева, он писал жене с колымской каторги 20 июня 1943: ““Из края в край, из града в град судьба, как вихрь, людей метет. И рад ли ты - или не рад - вперед, вперед, всегда вперед”. Вот и мои любимые стихи (еще с 1919 г., когда их впервые истолковал в Пушкинском кружке Андрей Белый) получили конкретную значимость для всех нас, да еще в самом трагическом варианте, о котором никто никогда и подумать не мог даже в бредовом кошмаре» (Зайцев 1990: 539). Последняя строка у Тютчева: «Что нужды ей?.. Вперед, вперед!». См. также отзыв о докладе Андрея Белого в письме Эйхенбаума и комментарий публикаторов: Жирмунская, Эйхенбаум 1988: 292-293, 327.

93 Референт - Андрей Белый - извинялся в письме к Венгерову от 6 ноября 1917: «Мне бесконечно больно и горько, что произошло недоразумение с заседанием. Я был введен в заблуждение слухами о железнодорожной забастовке и другими факторами, помешавшими приехать на прения по поводу моего доклада» (Лавров 1981: 54).

94 Письмо Клемана позволяет хотя бы приблизительно определить дату выступления Эйхенбаума в Пушкинском кружке - начало января 1918. В предисловии к «Мелодике русского лирического стиха», написанном летом 1921, Эйхенбаум не упомянул 
это деление казалось не слишком убедительным, так как Б. М. не дал достаточно существенных признаков для отличия ритма от мелодии. Мелодическая школа, к которой принадлежат Жуковский, Тютчев и Фет, шире пользовалась синтаксисом. <...> Кружок окончательно решил реформироваться в общество проект устава внесен в Совет<,> и мы ждем только утверждения, которое, конечно, не замедлит. Устав, составленный по образцу устава Неофилологического общества, рассчитан широко, предполагается издавать “труды”, но это вряд ли теперь осуществимо. $<\ldots .>»^{95}$.

В письме к С. А. Рейсеру от 16 марта 1954 Оксман вспоминал о занятиях у Н. М. Лисовского, который читал в университете курс книговедения: «Этому старику я обязан много больше, чем всему фил<ологическому> факультету <...> (Азадовский 1998: 104). В матрикуле запись к Лисовскому есть лишь за осень 1916 и весну $1917^{96}$, но сохранилось письмо Оксмана к Лисовскому, из которого следует, что работу о журнале «Московский вестник» ${ }^{97}$, защищенную у Шляпкина как выпускное сочинение, он писал вначале именно у него в 1914-1915 учебном году. Видимо, это был первоначальный вариант работы, судя по тому, как звучало ее название в письме к Шляпкину от 7 мая 1917 (см. прим. 16). Приведем письмо к Лисовскому от 27 июня 1915:

\section{«Дорогой Николай Михайлович!}

Очень извиняюсь, что не представил вам своевременно своей работы для сборника. В черновом виде она закончена уже давно, а окончательную отделку задержали экзамены, слухи о

об этом выступлении, он сообщал лишь, что работа была прочитана «в качестве пробной лекции в заседании историко-филологического факультета Петербургского университета, а затем - в виде доклада в заседании Неофилологического общества» (Эйхенбаум 1969: 327). Пробная лекция прошла 17 февраля 1918, см.: Жирмунская, Эйхенбаум 1988: 298.

95 РО ИРЛИ. Ф. 84. Ед. хр. 181. Л. 45-45 об. Недатированный и недописанный черновик. 96 См.: Д. 63266. Л. 23 об. Л. 24.

97 «Московский вестник» (1827-1830) издавался М. П. Погодиным, в нем печатался Пушкин. 
перенесении печати сборника на осень и, наконец, домашние мои обстоятельства. Как бы то ни было, теперь мне осталось лишь переписать свое “описание” и переслать вам. Структура его такова: 1) Введение, написанное по обсужденному с вами плану 2) Указатель к “Москов<скому> Вестнику”. 3) Примечания (выяснение псевдонимов, цензурные даты каждой книжки журнала, время выхода в свет каждого №, определенное по газетным публикациям) 4) Алфавитный указатель личных имен (авторов статей) к указателю журнала и перечень псевдонимов.

Работа, как видите, очень кропотливая, что отчасти может служить оправданием в задержке ее. <..>

Итак, дорогой Николай Михайлович, сообщите, выслать ли свою работу вам теперь или печатание сборника отложено? Будьте добры черкнуть хоть несколько слов о положении вообще дела с печатанием всем нам одинаково близкого библиографического альманаха.

Ваш Юлиан Оксман.

$19^{27 / \mathrm{VI}} 15$

Тирасполь (Херс<онской> губ.) Покровская, 88.

Юл. Гр. Оксману» ${ }^{98}$.

В записке Лисовского Оксману от 2 марта 1916 речь идет об этой же работе:

«Многоуважаемый

Юлиан Григорьевич.

Приеду в Петроград к Понедельнику. Быть может<,> Вы приготовите к этому времени Вашу работу. Дело со сборником (1 слово нрзб.) налаживается<,> несмотря на затруднение с бумагою. Расстройство жел<езных> дор<ог> совсем выбило меня из колеи и мешает правильности поездок.

2/III 1916 Ваш Лисов<ский $>{ }^{99}$.

98 РО ИРЛИ. Ф. 153. Ед. хр. 654. Л. 2-3.

99 Там же. Л. 10. 
Лисовский - чиновник в канцелярии военного министерства - жил в Москве и «приезжал на свой семинар раз в два месяца», - вспоминал Оксман в упомянутом выше письме к С. А. Рейсеру от 16 марта 1954 (Азадовский 1998: 104). Свою работу о «Московском вестнике» Оксман использовал, когда писал статью о пушкинской заметке, посвященной «Железной маске» (см.: Оксман 1917: 87-95).

Для получения выпускного свидетельства студент славянорусского отделения должен был получить зачет четырех просеминариев (см.: Обозрение 1912: 32). Оксман посещал упомянутые выше просеминарии Клочкова, Шляпкина и Щербы, четвертым он выбрал просеминарий Н. К. Пиксанова, посвященный Белинскому. В матрикуле Оксмана за 1913-1914 есть записи на лекции Пиксанова по историографии русской литературы ${ }^{100}$, хотя в Обозрении преподавания наук за 1913-1914 его курс не значится. Он появляется в следующем году под названием «Историография русской литературы нового периода (часть вторая; историкиакадемики, историки-публицисты, пушкинизм, новейшие течения)» (Обозрение 1914: 14), но в записях матрикула за 1914-1915 Пиксанова нет. Осенью 1916 и весной 1917 Оксман записался к Пиксанову в просеминарий по Тургеневу ${ }^{101}$. Зачет в просеминарии по Белинскому Оксман получил 24 марта 1917, за пять дней до выписки выпускного свидетельства ${ }^{102}$.

В письме к историку А. С. Нифонтову Оксман сообщал, что с 1915 служил «в архиве министерства народного просвещения, где дослужился до звания чиновника особых поручений VII класса <...» (Богаевская 1990: 100). По всей вероятности, именно с его слов В. Эджертон писал в некрологе: “As early as the summer of 1915 he had begun working in Russian archives, studying the history of Russian

\footnotetext{
${ }^{100}$ См.: Д. 63266. Л. 20 об. Л. 21.

101 Там же. Л. 23 об. Л. 24. См.: Обозрение 1916: 16.

102 См.: Д. 63266. Л. 18 об. - 19. 10 сентября 1965 Оксман писал Пиксанову, что, разбирая бумаги, «нашел свой доклад в семинарии по Белинскому, кот<орый> вы вели в 1914 - 1915 гг. Доклад на тему “Белинский о прозе Э. Т. А. Гофмана” (я ведь готовил дипломную работу о Гофмане в рус<ской> и франц<узской> литературе 20 - 30-х гг.)» (Азадовский 1998: 43).
} 
censorship and the press" (Edgerton 1973: 5). Вслед за американским ученым и первые публикаторы мемуарных фрагментов сообщали, что «начав занятия в архивах летом 1915 г., он с января 1916 участвует в Комиссии по научному описанию архива министерства народного просвещения <...>» (Чудакова, Тоддес 1984: 83-84) ${ }^{103}$. Сохранившиеся в студенческом деле документы 1916 позволяют уточнить дату начала занятий в архиве: это, во-первых, прошение Оксмана в министерство народного просвещения, во-вторых, полученный им из министерства ответ.

«Его Превосходительству Господину Директору Департамента Общих Дел Министерства Народного Просвещения студента Императорского Петроградского

Университета

Юлиана Григорьевича Оксмана

Прошение.

В течение нескольких лет изучая под руководством профессоров И. А. Шляпкина, А. П. Кадлубовского ${ }^{104}$, Н. М. Лисовского и Н. К. Пиксанова жизнь и критическую деятельность В. Г. Белинского, покорнейше прошу допустить меня к занятиям в Архиве Министерства Народного Просвещения для ознакомления с делами 1830 - 50-х годов, имеющими отношение к предпринятой мною научной работе.

Юлиан Оксман

4 апреля 1916 г.

Петроград

В. О., 8 линия, д. 49 б, кв. 27» ${ }^{105}$.

${ }^{103}$ Ср.: «В январе 1916 г. Оксман по рекомендации профессоров С. Ф. Платонова и И. А. Шляпкина был утвержден в должности младшего научного сотрудника Комиссии по научному описанию Архива МНП и проработал на этой должности до мая того же года» (Фролов 2013: 122). М. А. Фролов ссылается на автобиографию Оксмана от 10 июля 1956.

104 Арсений Петрович Кадлубовский (1867-1921) - специалист по древнерусской агиографической литературе, в его просеминарий Оксман записывался в 1915-1916 учебном году, см.: Д. 63266. Л. 22 об. Л. 23.

105 Там же. Л. 39. 
21 апреля 1916 прошение студента из министерства вернулось к ректору, чтобы тот дал свое заключение ${ }^{106}$. Ректор не возражал, и спустя неделю, 28 апреля 1916, студенту послали извещение:

«На поступившее в Департамент Об. Дел прошение студента Импер. Петроградского Университета Юлиана Оксмана Департ. Общих Дел объявляет, что просителю Департаментом разрешено заниматься в Архиве Мин. Нар. Пр. в присутственное время по указанию г. начальника Архива.

Вице-директор (подпись)

За делопроизводителя (подпись)» ${ }^{107}$.

Оксман получил извещение 13 мая $1916^{108}$. Надо полагать, что до этого времени никакие архивные занятия начаться не могли.

Высказывалось предположение, что Оксман женился, еще учась в университете, в 1915 или в 1916 (см.: Чудакова, Тоддес 1988: 98). До 1906 у студента была альтернатива: либо учиться, либо жениться ${ }^{109}$. В 1906 министерство народного просвещения предоставило высшим учебным заведениям право выдавать студентам разрешения вступать в брак, а также самостоятельно решать вопрос - принимать женатых людей в число студентов или нет. По этой причине в студенческих делах можно встретить три документа: прошение студента ректору, чтобы тот разрешил ему вступить в законный брак, письменное разрешение на это, и то, что очень условно можно назвать свидетельством о заключении брака. Такое свидетельство - не особый документ, а всего лишь запись священнослужителя, подтверждающего своей подписью и печатью совершение брака. Такая запись производилась на обороте другого

\footnotetext{
106 Там же. Л. 44.

107 Там же. Л. 40. копия.

108 Там же.

109 См. по теме монографию: М. Э. Кругляк. Життя та побут студентства підросійської України другої половини XIX - початку XX ст. Житомир: Волинь, 2015. См. авторское резюме по-русски: [http://www.historicus.ru/Jenitsa_ili_Uchitsa_Brak_v_povsednevnoi_ jizni_rossiskogo_studenchestva/]. Исследовательница упоминает в качестве обязательного документа для вступления в брак нотариально заверенное согласие родителей жениха; похожий документ нам не встретился ни в одном из дел женатых студентов.
} 
документа, который удостоверял личность студента, скажем, его право жить в столице. В качестве примера отсылаем к студенческим делам Тынянова и Эйхенбаума (см.: Сальман 2014: 460-461; 480). В деле Оксмана нет ни одного документа, который бы относился к матримониальным делам, можно предположить, что официальный брак с А. П. Семеновой был заключен Оксманом, когда он окончил университет.

После получения выпускного свидетельства 29 марта 1917 Оксман начал сдавать экзамены в государственной испытательной комиссии. В апреле он выдержал все экзамены ${ }^{110}$ и получил диплом первой степени, а четвертым мая 1917 датируется черновик его заявления об оставлении при университете ${ }^{111}$.

В неоднократно упоминавшемся письме к Шляпкину, написанном спустя три дня после этого заявления, Оксман сообщал, что за экзаменационными делами он позабыл выхлопотать отсрочку от воинской службы (см.: Рак, Эльзон 2003: 144). Она была ему дана, как оставленному при университете, но 10 октября 1917 Оксману пришлось явиться в Елисаветградское уездное присутствие по воинской повинности, чтобы получить временное свидетельство, которое подтвердило, что «Юлиан Гершев <sic! - M. C.> Оксман являлся к исполнению воинской повинности при досрочном призыве 1916 года и подлежал поступлению на службу в постоянные войска; <..> поступление ему на службу отсрочено до 1 числа месяца, следующего за окончанием образования, но не далее 1 Октября 1925 года, если к тому времени он не будет назначен на

\footnotetext{
110 На славяно-русском отделении сдавали шесть экзаменов: старославянский язык с палеографией, русский язык с диалектологией, история русской словесности, история западноевропейских литератур, один из южных и один из западных славянских языков с историей славянских литератур, сравнительная грамматика индоевропейских языков, см.: Обозрение 1912: 28-29. Осенью 1915 Оксман занимался болгарским языком у Н. С. Державина, а польским языком и польской литературой у С. Л. Пташицкого, см.: Д. 63266. Л. 22 об. Станислав Львович Пташицкий (1853-1933), приватдоцент по кафедре славянской филологии, см.: Отчет 1914: 21. Уехав в 1918 в Польшу, преподавал в Люблинском университете в 1919-1926, в 1926-1932 был директором польских архивов.

111 См.: РО ИРЛИ. Ф. 341. Оп. 1. Ед. хр. 369. Оксман «был оставлен при кафедре с 20 мая 1917 года <...» (Рак, Эльзон 2003: 145).
} 
должность<,> совершенно освобождающую от воинской повинности» ${ }^{12}$.

Вернувшись в Петроград, который он, подобно большинству столичных жителей, продолжал называть Петербургом, Оксман пишет Лисовскому в Москву. Штемпелей на конверте нет (по всей вероятности, письмо было передано с оказией, с А. С. Николаевым, см. ниже), дата поставлена карандашом, видимо, адресатом; как человек педантичный, он ставит карандашом и номер - письмо 27. Прежде чем привести текст, напомним о некоторых реалиях того времени.

Осенью 1917 столица голодала, в конце августа Оксман писал А. П. Семеновой: «Жить невыносимо трудно - кроме хлеба, который получаю по карточке, я ничего не видел даже съестного, кроме овощей <...» (Зайцев 1990: 529). 7 сентября центральная продовольственная управа сообщала, что с 8 сентября хлебный паек составит три четверти фунта по основной карточке (см.: День. 1917. № 157. 7 сентября. С. 5) ${ }^{113}$. В этот же день газета извещала о разгроме дворцов: «По распоряжению комиссариата $6<$ ывшего> министерства двора производится осмотр Царскосельского, Александровского и Стрельнинского дворцов, подвергшихся разгрому 28 и 29 августа $<\ldots>$ исчезли подлинно художественные ценности $<\ldots .>$ Похищены миниатюры Ватто, несколько исторических гобеленов, редкий фарфор <...» (Там же: 4). После того как 21 августа немцы взяли Ригу, была открыта дорога на Петроград, и правительство приняло решение о «разгрузке» столицы ${ }^{114}:$ предполагалось эвакуировать как государственные учреждения, так и людей, а для въезда в город надо было получать специальное разрешение ${ }^{115}$.

Письмо Оксмана Лисовскому, написанное 18 октября 1917:

\footnotetext{
112 Д. 63266. Л. 7.

113 Один фунт равен 409,5 гр.

114 В апреле 1918 в Центральной коллегии по разгрузке Петрограда служил Мандельштам, см.: Мандельштам 2014: 137.

115 Г. В. Маслов писал из Симбирска в университетскую канцелярию 14 ноября 1917 и просил выслать ему разрешение на въезд в Петроград для сдачи экзаменов, см.: ЦГИА СПб. Ф. 14. Оп. 3. Д. 62271. Л. 48-48 об. Л. 43. Копия. Дата на Л. 43 об.
} 
«Глубокоуважаемый и дорогой

Николай Михайлович!

Вы совсем, очевидно, забыли своих покинутых в Петербурге учеников и, если бы не чрезвычайные обстоятельства последнего времени, не решился бы я об этом Вам напоминать. Вместо предисловия замечу только, что после нашего последнего свидания я успел уже окончить университет, числюсь оставленным по кафедре рус $<$ ского $>$ яз<ыка $>$ и словесности и недавно назначен заведующим цензурным архивом (б<ывшего $>$ Глав<ного $>$ Управления и Комитета по делам печати) на правах помощника начальника Архива Мин<истерства $>$ Нар<одного> Просв<ещения > VII класса $^{116}$.

В распоряжении моем теперь свыше 50 тысяч “дел”, записок, секрет<ных> изданий и коллекций, - грандиозный материал по истории культуры, литературы, журналистики, библиографии и иконографии. Разбор всего материала не успел, однако, дойти даже до середины, как предложение об эвакуации сразу выбило всех из колеи.

С большим трудом удалось добиться разрешения на перевоз архива в Москву, причем выбор ее в значительной степени был для меня определен мыслью о Вашем содействии, советах и авторитетных указаниях при разборе цензурных сокровищ.

Для предварительных розысков помещения и выяснения всех условий эвакуации на месте в Москву выезжает Начальник Архива Минист<ерства> Народ<ного> Просвещения - Алек$<$ сандр $>$ Серг <еевич> Николаев ${ }^{117}$, уполномоченный (кроме того) Археографич<еской> Комиссии, Всерос<сийского $>$ союза архивных деятелей и Пушкинского дома.

Интересы всех этих учреждений меня сейчас мало занимают, но устройство цензурного архива заставляет обратиться к Вам,

\footnotetext{
116 В автобиографии 1949 Оксман сообщал, что был назначен помощником начальника архива 1 июня 1917, см.: Зайцев 1990: 531.

117 Александр Сергеевич Николаев (1877-1934), архивист, подробнее см.: Фролов 2013: 116-123. В письме к В. Д. Бонч-Бруевичу от 3 апреля 1934 Оксман писал, что «был очень близок к А. С. Николаеву (в 1921 г. мы выпустили под нашей общей редакцией истор<ико>-лит<ературный> альманах “Литературный Музеум” <...> (Там же. 119).
} 
Николай Михайлович, с горячей просьбой не оставить своей поддержкой и компетентными указаниями моего начальника в его Московских хождениях по мукам. Боюсь быть чрезмерно уж нескромным, но - помнится - вы как-то говорили о больших размерах своей квартиры: было бы большим счастьем, если бы Вы уступили ведомству Народ<ного> Просвещ<ения> хоть две комнатки для эвакуируемых лиц (меня в том числе) и наиболее ценных предметов.

Разумеется, надеяться на это я не смею, но с середины ноября наше научное общение в Москве во всяком случае восстановится: цензурный архив ждет Ваших предначертаний.

Еще раз простите за невольное беспокойство, которое Вам, может быть, причиняю этим письмом.

Ваш Юл. Оксман.

Если захотите черкнуть несколько слов до моего отъезда из Петербурга, то адрес старый: Зверинская, 7, кв. 1.

Юлиану Григорьевичу Оксману» ${ }^{118}$.

Этим письмом (свидетельством времени), написанным за неделю до Октябрьского переворота, мы и завершаем статью. Годы 1918-1923 в жизни Оксмана, проведенные в Петрограде и Одессе, нуждаются в отдельном исследовании.

\section{БИБЛИОГРАФИЯ}

Абросимова В. 1998. Ахматовский мотив в письмах А. В. Белинкова к Ю. Г. Оксману / Вступительная заметка, публикация и комментарий В. Абросимовой. - Знамя. № 10. С. 139-147.

Азадовский К. М. 1998. Азадовский М. К., Оксман Ю. Г. Переписка 19441954 / Изд. подготовил Константин Азадовский. М.: Новое литературное обозрение.

Бейер Т. 1988. Осип Мандельштам и Гейдельбергский университет / Публикация Т. Бейера. - Минувшее. Paris: Atheneum. [T.] 5. С. 222-225. Богаевская К. П. 1990. Возвращение. О Юлиане Григорьевиче Оксмане / Вступительная заметка и примечания И. Д. Прохоровой. - Литературное обозрение. № 4. С. 100-112.

${ }^{118}$ РО ИРЛИ. Ф. 153. Ед. хр. 654. Л. 5 - Л. 6 об. 
Богаевская К. П., Черных В. А. 1997. Список печатных трудов Ю. Г. Оксмана (к 100-летию со дня рождения). - Археографический ежегодник за 1995 год. М.: Наука. С. 327-340.

Богомолов Н. А. 2010. Вокруг «серебряного века»: Статьи и материалы. М.: Новое литературное обозрение.

Брокгауз, Ефрон 1890. Энциклопедический словарь Ф. А. Брокгауза и И. А. Ефрона. Т. Іа. СПб.: Семеновская типолитография (И. А. Ефрона). Брюсов В. Я. 1916. [Рец.] Пушкинист. Вып. ІІ. - Известия московского литературно-художественного кружка. Вып. 14-15. С. 79-82.

Венгеров С. А. 1918. [Предисловие]. - Пушкинист. Историко-литературный сборник. III. Пг. С. V-X.

Водонос Е., Филиппов А. 1994. Письма Ю. Г. Оксмана Р. А. Резник / Публикация Е. Водоноса, А. Филиппова. - Волга. № 1. С. 104-121.

Вознесенский А. 1916. [Рец.] Пушкинист. Историко-литературный сборник. II. - Русский филологический вестник. № 3. С. 174-178.

Высылка 2005. Высылка вместо расстрела. Депортация интеллигенции в документах ВЧК - ГПУ. 1921-1923 / Вступительная ст., сост. В. Г. Макарова, В. С. Христофорова; комментарии В. Г. Макарова. М.: Русский путь.

[Гельбке Ф. Ф.] 1912. Календарь для учителей на 1912-1913 уч. год. Ч. II. СПб.: Издание Отто Кирхнер.

Гришунин А. Л. 1999. Проблемы пушкинской текстологии в оценке Ю. Г. Оксмана. - Известия АН. Серия литературы и языка. Т. 58. № 3. С. 3-17. Гуревич Я. Г. 1899. К вопросу о реформе системы среднего образования, в особенности же классической гимназии. - Русская школа. № 11. C. 124-146.

Жирмунская Н. А., Эйхенбаум О. Б. 1988. Переписка Б. М. Эйхенбаума и В. М. Жирмунского / Публикация Н. А. Жирмунской и О. Б. Эйхенбаум; вступительная ст. Е. А. Тоддеса; примечания Н. А. Жирмунской и Е. А. Тоддеса. - Тыняновский сборник. Третьи Тыняновские чтения. Рига: Зинатне. С. 256-329.

Зайцев А. Д. 1990. «Человек жизнерадостный и жизнедеятельный...» (Набросок портрета Ю. Г. Оксмана по материалам его архива) / Обзор А. Д. Зайцева. - Встречи с прошлым. Вып. 7. М.: Советская Россия. С. 525-566.

Измайлов Н. В. 1960. Б. В. Томашевский как исследователь Пушкина. Пушкин. Исследования и материалы. Т. III. С. 5-24. 
Каганович Б. С. 2006. Наука и политика в биографии Ю. Г. Оксмана (Некоторые материалы и соображения). - Историческое сознание и власть в зеркале России ХХ века. СПб.: Нестор-История. С. 50-64.

Кертис Дж. 2004. Борис Эйхенбаум: Его семья, страна и русская литература. СПб.: Академический проект.

Клеман М. К. 1922. Текст лицейских стихов Пушкина. - Пушкинский сборник. Памяти профессора Семена Афанасьевича Венгерова. Пушкинист IV. М.; Пг.: Госиздат. С. 1-12.

КЛЭ 1968. Краткая литературная энциклопедия: В 9-ти тт. М.: Советская энциклопедия. Т. 5.

Кругляк М. Э. 2015. Життя та побут студентства підросійської України другої половини XIX - початку XX ст. Житомир: Волинь.

Лавров А. В. 1981. Материалы Андрея Белого в Рукописном отделе Пушкинского Дома. - Ежегодник рукописного отдела Пушкинского Дома на 1979 год. Л.: Наука. Ленинградское отделение. С. 29-79.

Лернер Н. О. 1913. Стихи Пушкина о Марино Фальери. - Русский библиофил. 1913. № 2. С. 25-31.

ЛЭ 1934. Литературная энциклопедия: В 11-ти тт. М.: Советская энциклопедия. T. VIII.

Мандельштам О. Э. 1990. Камень / Изд. подготовили Л. Я. Гинзбург, А. Г. Мец, С. В. Василенко, Ю. Л. Фрейдин. Л.: Наука.

Мандельштам О. Э. 2009-2011. Полн. собр. соч. и писем: В 3-х тт. М.: Прогресс-Плеяда.

Мандельштам О. Э. 2014. Полн. собр. соч. и писем: В 3-х тт. Приложение. Летопись жизни и творчества. М.: Прогресс-Плеяда.

Обозрение 1912. Обозрение преподавания наук на историко-филологическом факультете императорского С.-Петербургского университета в осеннем полугодии 1912 года и в весеннем полугодии 1913 года. СПб.

Обозрение 1913. Обозрение преподавания наук на историко-филологическом факультете императорского С.-Петербургского университета на 1913-1914 учебный год. СПб.

Обозрение 1914. Обозрение преподавания наук на историко-филологическом факультете императорского Петроградского университета в осеннем полугодии 1914 года и в весеннем полугодии 1915 года. Пг.

Обозрение 1916. Обозрение преподавания наук на историко-филологическом факультете императорского Петроградского университета 
в осеннем полугодии 1916 года и в весеннем полугодии 1917 года. Пг.

Оксман О. Э. 2008. Семейные хроники. Воспоминания. Одесса: Астропринт.

Оксман Ю. Г. 1915. К вопросу о дате стихов Пушкина о старом доже и догарессе молодой. - Русский библиофил. № 3. С. 90-94.

Оксман Ю. Г. 1916. Программа драмы А. С. Пушкина о паписсе Иоанне (К истории недовершенного замысла). - Пушкинист. Историко-литературный сборник II. Пг.: Фототипия и типография А. Ф. Дресслера. С. 258-268.

Оксман Ю. Г. 1917. Сюжеты Пушкина (Отрывочные заметки). - Пушкин и его современники. Материалы и исследования. Пг. Вып. XXVIII. С. 73-95.

Оксман Ю. Г. 1922. Сюжеты Пушкина (Отрывочные замечания). - Пушкинский сборник. Памяти профессора Семена Афанасьевича Венгерова. Пушкинист IV. М.; Пг.: Госиздат. С. 24-39.

Оксман Ю. Г. 2005. Николай Осипович Лернер / Вступительная ст. и публикация С. И. Панова. - Пушкин и его современники. Сборник научных трудов. СПб.: Нестор-История. Вып. 4 (43). С. 164-214.

Оксман Ю. Г. - Чуковский К. И. 2001. Переписка / Предисловие и комментарий А. Л. Гришунина. М.: Языки славянской культуры.

Отчет 1914. Отчет о состоянии и деятельности императорского С.-Петербургского университета за 1913 год. СПб.: Типография Б. М. Вольфа.

Отчет 1915. Отчет о состоянии и деятельности императорского Петроградского университета за 1914 год. Пг.: Типография Б. М. Вольфа.

Перченок Ф. Ф. 1995. К истории Академии наук: Снова имена и судьбы... In memoriam: Исторический сборник памяти Ф. Ф. Перченка / Сост. А. И. Добкин, М. Ю. Сорокина. М.; СПб.: Феникс; Atheneum. С. 141-210. Писатели-диссиденты 2004 Биобиблиографические статьи. - Новое литературное обозрение. № 67. С. 418-436.

Протоколы 1914. Протоколы заседаний Совета императорского С.-Петербургского университета за 1912 год. № 68. СПб.

Протоколы 1915. Протоколы заседаний Совета императорского С.-Петербургского университета за 1913 год. № 69. Пг.

Протоколы 1916. Протоколы заседаний Совета императорского Петроградского университета за 1914 год. № 70. Пг. 
Пугачев В. В., Динес В. А. 1995. Историки, избравшие путь Галилея: Статьи, очерки. Посвящается 100-летию Юлиана Григорьевича Оксмана. Саратов: Издательский центр Саратовской государственной экономической академии.

Пушкарев С. Г. 1999. Воспоминания историка. 1905-1945. М.: Посев.

Пушкинист 1916а. Историко-литературный сборник. II. Пг. С. 287-289.

Пушкинист 1916б. Историко-литературный сборник. ІІ. Пг. С. 290-292.

Рак В. Д., Эльзон М. Д. 2003. «Искренне Ваш Юл. Оксман» (Письма 19141970-х годов) / Публикация М. Д. Эльзона, предисловие В. Д. Рака, примечания В. Д. Рака и М. Д. Эльзона. - Русская литература. № 3. С. 137-184.

Рак В. Д., Эльзон М. Д. 2006. «Искренне Ваш Юл. Оксман». (Письма 19141970-го годов) / Публикация М. Д. Эльзона, предисловие В. Д. Рака, примечания В. Д. Рака и М. Д. Эльзона. - Русская литература. № 1. С. 227-273.

Русские писатели 1989-1999. Биографический словарь. 1800-1917. Т. 1-4. М.: «Большая Российская энциклопедия».

Сальман М. Г. 2010. Осип Мандельштам: Годы учения в Санкт-Петербургском университете (по материалам Центрального государственного исторического архива Санкт-Петербурга) - Russian Literature. Vol. LXVIII. Nos. III/IV. C. 447-499.

Сальман М. Г. 2014. Из студенческих лет Б. М. Эйхенбаума, Ю. Н. Тынянова и В. Б. Шкловского (По материалам Центрального государственного исторического архива Санкт-Петербурга). - Russian Literature. Vol. LXXVI. No. IV. C. 447-509.

Степун Ф. А. 2000. Бывшее и несбывшееся / Послесловие Р. Гергеля. 2-е изд., исправленное. СПб.: Алетейя.

Струве Г. П. 1979. [Предисловие] / К истории русской поэзии 1910-х начала 1920-х годов. - Modern Russian Literature and Culture. Studies and Texts. Berkeley. Vol. 1. C. 13-28.

С<труве> Н. А. 1990 (III). Мандельштам в Париже. - Вестник РХД. № 160. С. 255-257.

Сухих И. Н., Шубин В. Ф. 1989. «Так началась моя работа...» (Юрий Тынянов в Петербургском - Петроградском университете). Очерки по истории Ленинградского университета. Л.: ЛГУ. VI. C. $45-54$. 
«Тамиздат» 1990. От осуждения к диалогу. Саратов: Издательство Саратовского университета. Вып. 6.

Тименчик Р. Д. 2010. Около акмеизма. - Vademecum: К 65-летию Лазаря Флейшмана / Сост. и ред. Андрея Устинова. М.: Водолей. С. 168-196.

Томашевский Б. В. 1923. Заметки о Пушкине. - Пушкин и его современники. Пб. Вып. 36. С. 78-95.

Тынянов Ю. Н. 1977. Поэтика. История литературы. Кино / Предисловие В. А. Каверина; изд. подготовили Е. А. Тоддес, А. П. Чудаков, М. О. Чудакова. М.: Наука.

Устинов А. Б. 1994. Письма Ю. Г. Оксмана к Л. Л. Домгеру / Предисловие, комментарий А. Б. Устинова. - Themes and Variations: In Honor of Lazar Fleishman. = Темы и вариации: Сборник статей и материалов к 50-летию Л. Флейшмана. С. 470-544. (Stanford Slavic Studies. Vol. 8).

Флейшман Л. С. 1987. Из архива Гуверовского института. Письма Ю. Г. Оксмана к Г. П. Струве / Публикация Лазаря Флейшмана. - Stanford Slavic Studies. Vol. 1. Stanford: Berkeley Slavic Specialties. С. 15-70.

Фомин А. Г. 1922. С. А. Венгеров как профессор и руководитель Пушкинского семинария. - Пушкинский сборник. Памяти профессора Семена Афанасьевича Венгерова. Пушкинист IV. М.; Пг.: Госиздат. С. ХXXXIII.

Фролов М. А. 2013. «Надеюсь, что успеем материал спасти». Роль Ю. Г. Оксмана и В. Д. Бонч-Бруевича в деле сохранения личного архива А. С. Николаева. 1934 г. / Вступительная ст., подготовка текста и комментарии М. А. Фролова. - Отечественные архивы. № 2. С. 116-123.

Фролов М. А. 2014. Юлиан Григорьевич Оксман (1895-1970). Краткий обзор научной биографии. - Филологические науки. № 5. С. 111-120.

Чудакова М. О., Тоддес Е. А. 1984. Тынянов в воспоминаниях современника (сообщение). - Тыняновский сборник. Первые Тыняновские чтения (г. Резекне, май 1982). Рига: «Зинатне». С. 78-104.

Чудакова М. О., Тоддес Е. А. 1988. Из переписки Ю. Г. Оксмана. / Вступительная ст. и примечания М. О. Чудаковой и Е. А. Тоддеса. - Четвертые Тыняновские чтения: Тезисы докладов и материалы для обсуждения. Рига: «Зинатне». С. 96-168.

Чухлий С. А. 2010. Историк в переломную эпоху: Перипетии судьбы и зигзаги научного творчества профессора М. В. Клочкова. - Харківський історіографічний збірник. Х.: ХНУ імені В. Н. Каразіна. Вип.10. С. 265274. 
Шруба М. 2004. Литературные объединения Москвы и Петербурга 18901917 годов: Словарь. М.: Новое литературное обозрение.

Эйдельман Н. Я. 1999. Из дневников / Вступительная заметка, публикация и комментарии Юлии Эйдельман. - Знамя. № 1. С. 137-161.

Эйхенбаум Б. М. 1969. О поэзии. Л.: Советский писатель.

Becher, M. 2010. Wilhelm Levison (1876-1947): ein jüdisches Forscherleben zwischen wissenschaftlicher Anerkennung und politischem Exil. Siegburg: Schmitt.

Edgerton, William B. 1973. Julian Grigor'evic Oksman 1895-1970. - Russian Literature. Vol. 2. No. 3. P. 5-34. 


\section{Grobherzoglich Badische Ruprecht-Karls-Universität}

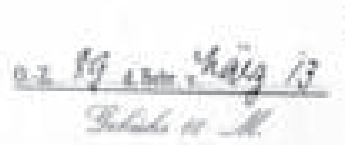

Heidelberg.

$+2 / z$ es

\section{Albgangs-Zeugnis.}

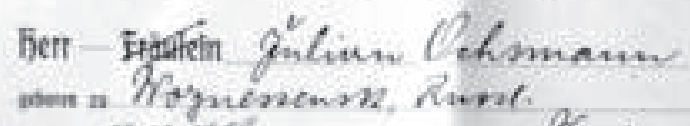

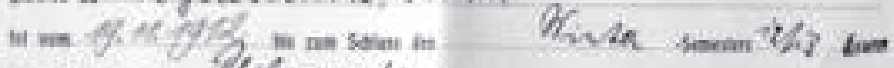
as somente an thiloviakie

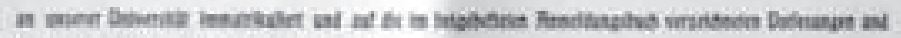

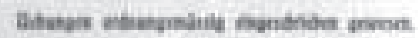

-3 sorar $129+2$

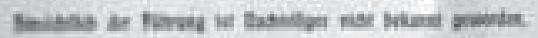

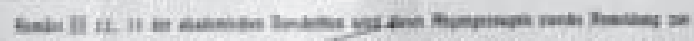

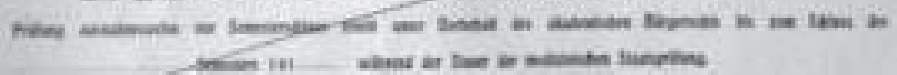

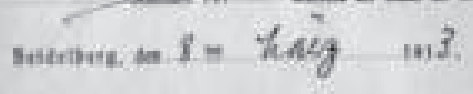

Det Protcilot:

Det akaderiute Disziplasteante:

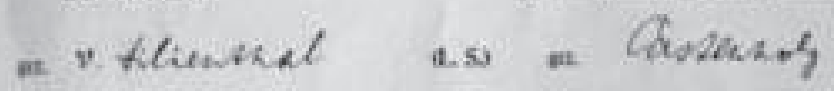

Илл. 1. Свидетельство об окончании зимнего семестра 08.03.1913

Гейдельберг 


\section{Königlich Preussische Rheinische}

\section{Friedrich-Wilhelms-Universität}

\&u

\section{BONN}

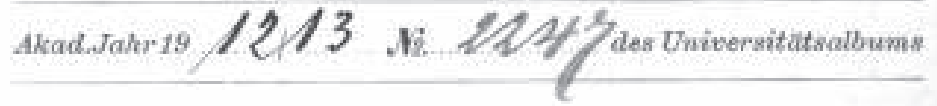

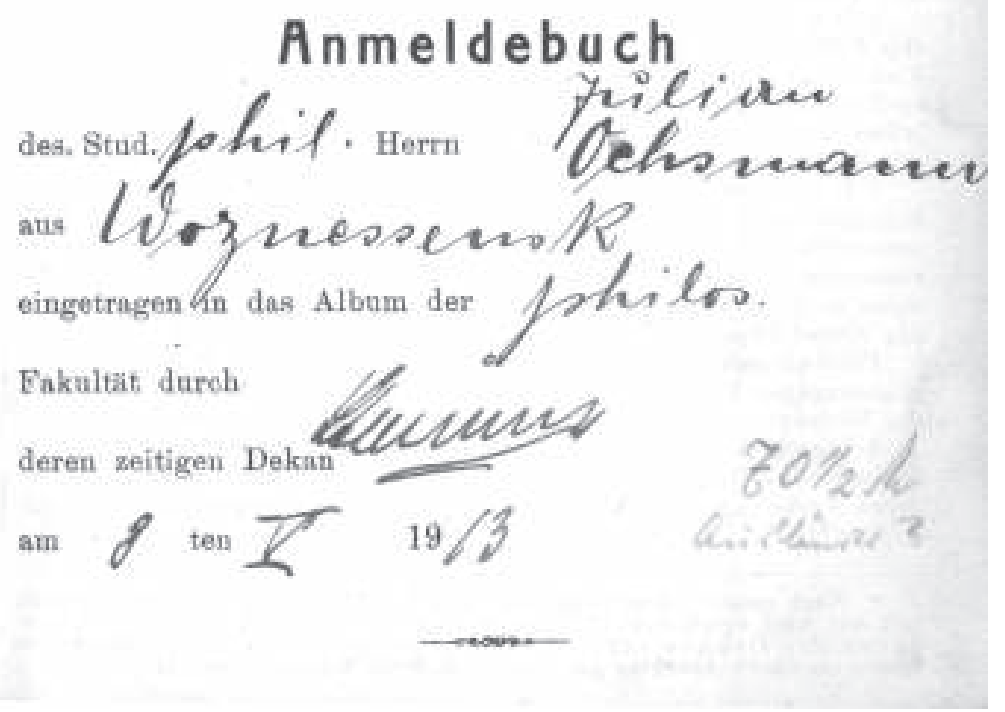

Илл. 2. Anmeldebuch. Бонн. 1913. 


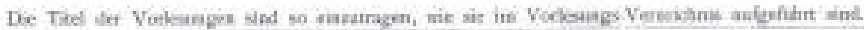

Somamer halbjahr 1913

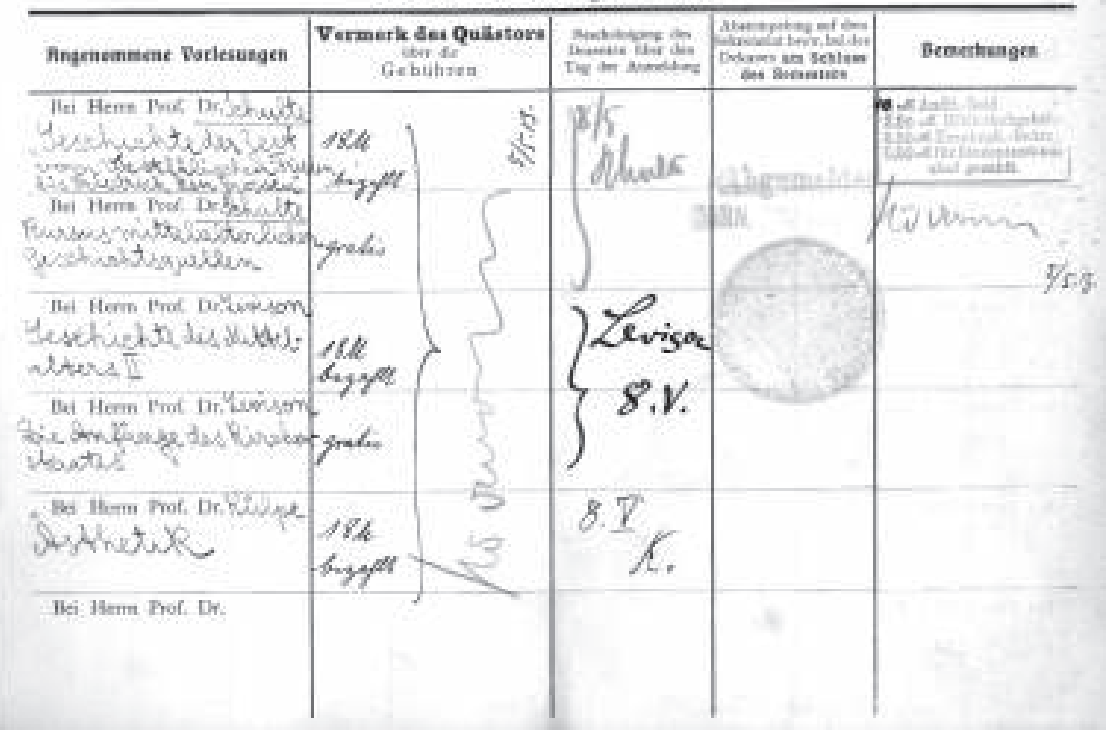

Илл. 3. Anmeldebuch. Разворот. Бонн. 1913. 

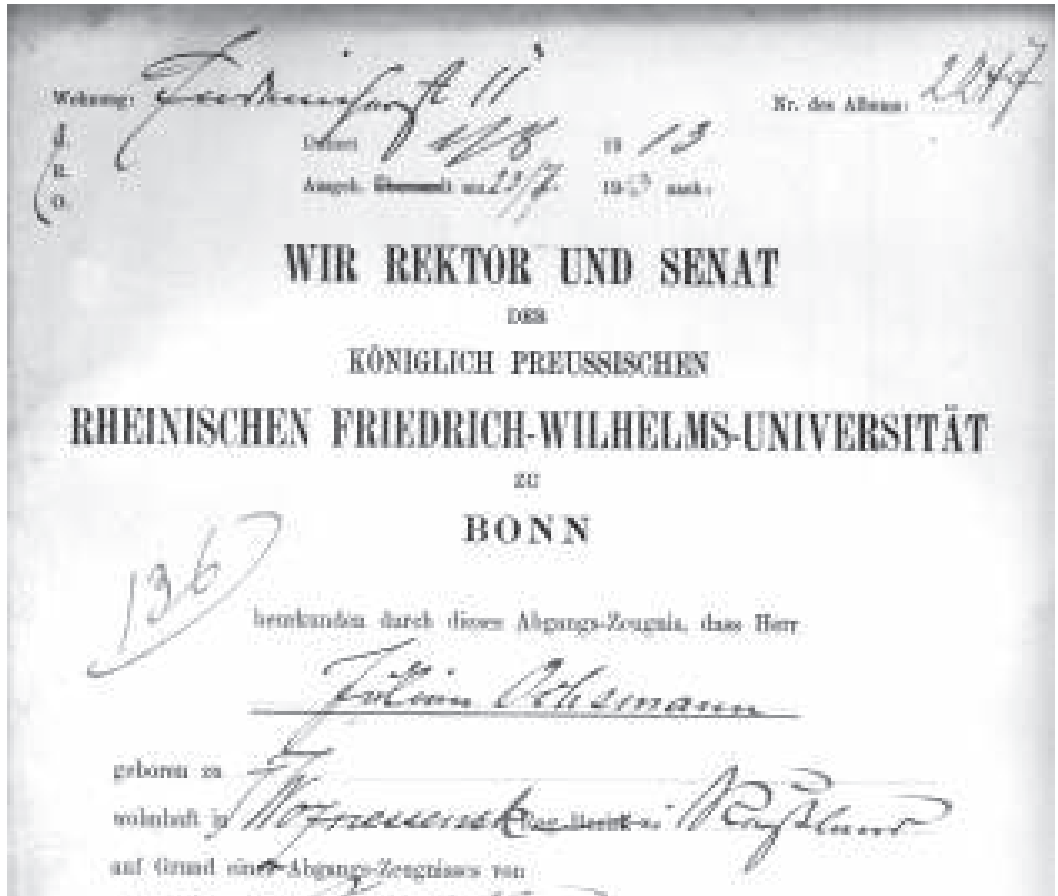

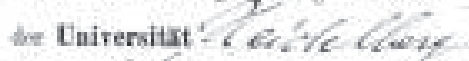

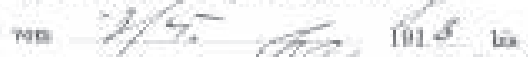

als Stediarabe der

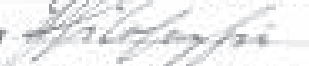

on der hierigeo Lafresian inasikilient genesen lat,

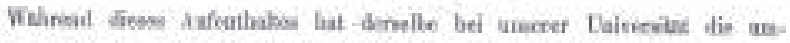

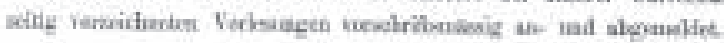

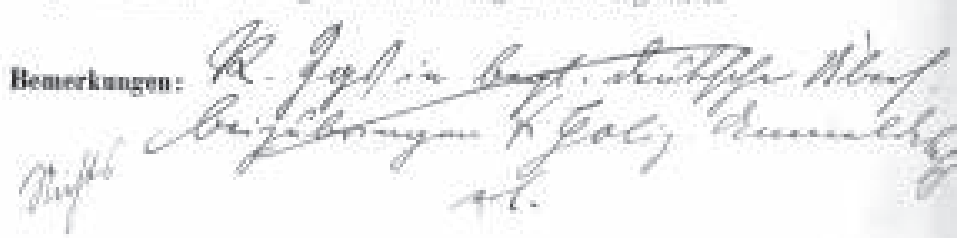

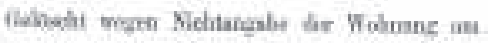

$$
\begin{aligned}
& \text { n - Sichandolian ther Zahillarie an } \\
& \text { H } \quad \text { Sitamalnas nan Vochanges }
\end{aligned}
$$

Илл. 4. Справка об эксматрикуляции. 23. 07. 1913. Бонн. 